\title{
A process-based fire parameterization of intermediate complexity in a Dynamic Global Vegetation Model
}

\author{
F. Li ${ }^{1}$, X. D. Zeng ${ }^{1}$, and S. Levis ${ }^{2}$ \\ ${ }^{1}$ International Center for Climate and Environmental Sciences, Institute of Atmospheric Physics, Chinese Academy of \\ Sciences, Beijing, China \\ ${ }^{2}$ Terrestrial Sciences Section, Climate and Global Dynamics Division, National Center for Atmospheric Research, Boulder, \\ Colorado, USA
}

Correspondence to: F. Li (lifang@mail.iap.ac.cn)

Received: 17 January 2012 - Published in Biogeosciences Discuss.: 16 March 2012

Revised: 19 June 2012 - Accepted: 2 July 2012 - Published: 30 July 2012

\begin{abstract}
A process-based fire parameterization of intermediate complexity has been developed for global simulations in the framework of a Dynamic Global Vegetation Model (DGVM) in an Earth System Model (ESM). Burned area in a grid cell is estimated by the product of fire counts and average burned area of a fire. The scheme comprises three parts: fire occurrence, fire spread, and fire impact. In the fire occurrence part, fire counts rather than fire occurrence probability are calculated in order to capture the observed high burned area fraction in areas of high fire frequency and realize parameter calibration based on MODIS fire counts product. In the fire spread part, post-fire region of a fire is assumed to be elliptical in shape. Mathematical properties of ellipses and some mathematical derivations are applied to improve the equation and assumptions of an existing fire spread parameterization. In the fire impact part, trace gas and aerosol emissions due to biomass burning are estimated, which offers an interface with atmospheric chemistry and aerosol models in ESMs. In addition, flexible time-step length makes the new fire parameterization easily applied to various DGVMs.

Global performance of the new fire parameterization is assessed by using an improved version of the Community Land Model version 3 with the Dynamic Global Vegetation Model (CLM-DGVM). Simulations are compared against the latest satellite-based Global Fire Emission Database version 3 (GFED3) for 1997-2004. Results show that simulated global totals and spatial patterns of burned area and fire carbon emissions, regional totals and spreads of burned area, global annual burned area fractions for various vegetation types, and interannual variability of burned area are reason-
\end{abstract}

able, and closer to GFED3 than CLM-DGVM simulations with the commonly used Glob-FIRM fire parameterization and the old fire module of CLM-DGVM. Furthermore, average error of simulated trace gas and aerosol emissions due to biomass burning is $7 \%$ relative to GFED3. Results suggest that the new fire parameterization may improve the global performance of ESMs and help to quantify fire-vegetationclimate interactions on a global scale and from an Earth system perspective.

\section{Introduction}

Fire is critical in Earth system modeling on a global scale due to the close fire-vegetation-climate interactions (Bowman et al., 2009). On the one hand, vegetation and climate regulate fire occurrence and spread by determining fuel load, fuel flammability, and fire spread rate (van der Werf et al., 2008; Archibald et al., 2009). On the other hand, fire has important feedbacks on vegetation and climate. First, fire plays an integral role in shaping global vegetation (Sousa, 1984). Bond et al. (2004) suggested that closed forests would double from $27 \%$ to $54 \%$ of vegetated grid cells in a world without fire. Second, due to vegetation-climate interactions, fire can affect water, energy and momentum between land and atmosphere indirectly by changing vegetation characteristics (Chambers and Chapin, 2002; BondLamberty et al., 2009). Third, global fire carbon emissions, which were around $2.1 \mathrm{Pg} \mathrm{C} \mathrm{yr}^{-1}$ with large interannual variability (1.4-3.2 $\mathrm{Pg} \mathrm{C} \mathrm{yr}^{-1}$ ) from 1960 to 2009 (Schultz et 
al., 2008; van der Werf et al., 2010), significantly affect the global net land-to-atmosphere carbon flux, whose mean value was about $-0.7 \mathrm{Pg} \mathrm{Cyr}^{-1}$ from 1980 to 2004 (IPCC, 2007). In addition, biomass burning emits not only over $40 \%$ of the global black carbon and abundant greenhouse gases that contribute to climate warming, but also $\sim 30 \%$ of the global cloud condensation nuclei (CCN) (Day, 2004; Arora and Boer, 2005) that decrease the precipitation efficiency of clouds (Andreae et al., 2004; Lindsey and Fromm, 2008).

A Dynamic Global Vegetation Model (DGVM) (grid cell size: $10^{3}-10^{5} \mathrm{~km}^{2}$ ) simulates global vegetation succession dynamically and integrates biogeochemistry, biogeography, and vegetation dynamics of the land surface into a single and physically consistent framework (Foley et al., 1996; Sitch et al., 2003; Quillet et al., 2011). A DGVM may be coupled to atmospheric general circulation models (AGCMs) to simulate vegetation-atmosphere interactions in the framework of Earth System Models (ESMs) (Levis et al., 1999; Brovkin et al., 2006; Delire et al., 2011). A fire-enabled DGVM in an ESM is the quantitative assessment tool of global firevegetation-climate interactions from an Earth system perspective.

Current fire parameterization schemes in DGVMs can be divided into three types. The first type is simple in structure and light in computational burden, including the fire parameterization schemes in TRIFFID (Cox, 2001), IBIS (Kucharik et al., 2000), ED (Moorcroft et al., 2001), VEGAS-DGVM (Zeng et al., 2005) and SDGVM (Woodward and Lomas, 2004). TRIFFID prescribes a constant loss rate attributed to disturbance, and hence cannot model fire as a climatedependent and vegetation-dependent process in the context of global change. The other four DGVMs assume fire to be a simple empirical function of litter moisture content and/or litter amount, whose fire simulations have not been evaluated against the observations. Generally, this type of parameterization does not explicitly estimate the burned area and fire emissions, which are primary fire-related variables in the ESMs. The second type, by contrast, is represented by complex process-based fire parameterization schemes, such as MC-FIRE (Lenihan and Neilson, 1998) in MC-DGVM (Bachelet et al., 2003) and SPITFIRE in LPJ-SPITFIRE (Thonicke et al., 2010). Both schemes introduce a great number of equations and parameters to distinguish fire behaviors among various fuel types and between surface fire and crown fire. MC-FIRE assumes one ignition per year per grid cell, and its performance is evaluated only in the United States rather than on a global scale (http://www.fs.fed.us/pnw/mdr/ mapss/fireforecas-ts/methods.shtml). The LPX (Prentice et al., 2011), a modified LPJ-SPITFIRE, performed better in global total of annual burned area than the process-based fire parameterizations of intermediate complexity (Kloster et al., 2010); however, its lower skill in global spatial patterns does not justify its more complex design.

The third type is process-based fire parameterization of intermediate complexity. Schemes of this type include Glob-
FIRM (Thonicke et al., 2001) and CTEM-FIRE (Arora and Boer, 2005). Glob-FIRM is the most commonly used, and has been used as a fire module in LPJ (Sitch et al., 2003), SEIB-DGVM (Sato et al., 2007), CLM3-DGVM (Levis et al., 2004), ORCHIDEE (Krinner et al., 2005), CoLMDGVM (Dai et al., 2003; Chen, 2008), and CLM4-CNDV (Oleson et al., 2010; Lawrence et al., 2011; Castillo et al., 2012). Some of them, such as CLM3-DGVM, have incorporated the Glob-FIRM with minor changes. Compared with the first two types, this type of parameterization can capture the major processes of fire dynamics with efficient computation.

Existing parameterization schemes belonging to the third type have shortcomings. For example, Glob-FIRM does not account for the availability of ignition sources, the impact of wind speed on fire spread, and the incomplete combustion of plant tissues in post-fire regions. In CTEM-FIRE, humancaused ignition probability and cloud-to-ground lightning fraction are simply assumed to be constant globally; and the equations and assumptions for calculating the burned area are not self-consistent (see Sect. 2.2 in this paper). Moreover, though CTEM-FIRE simulates global burned area well when human-caused ignition probability is set to be 0.5 , it considerably underestimates the annual burned area in the tropical savannas and boreal Asia (Kloster et al., 2010), which are areas of high fire frequency according to 2001-2009 MODIS Monthly Active Fire Count product (Giglio et al., 2006) (Fig. 1).

In this study, we develop a process-based fire parameterization of intermediate complexity that overcomes these shortcomings. In addition, estimation of trace gas and aerosol emissions due to biomass burning is introduced, which offers an interface with atmospheric chemistry and aerosol models in ESMs. It is important for ESMs to capture the fireatmospheric chemistry and composition-climate-vegetation interactions, and to estimate greenhouse gas and aerosol forcing of climate more reasonably in global change projections (Thornton et al., 2008). Then, using a DGVM as a model platform, the simulated burned area and fire emissions are evaluated against the satellite-based global fire product, GFED3 (Giglio et al., 2010; van der Werf et al., 2010). The structure of this paper is as follows. Section 2 describes the new fire parameterization scheme. Section 3 briefly introduces the DGVM and the application of the fire parameterization in the model. Section 4 outlines the data for the simulation and evaluation. Section 5 presents the global performance of the developed fire parameterization. Conclusions and discussions are provided in Sect. 6 .

\section{Fire parameterization}

A basic equation of the new fire parameterization is that burned area in a grid cell per time step, $A_{\mathrm{b}}\left(\mathrm{km}^{2}\right.$ (time step $)^{-1}$ ), is determined by 


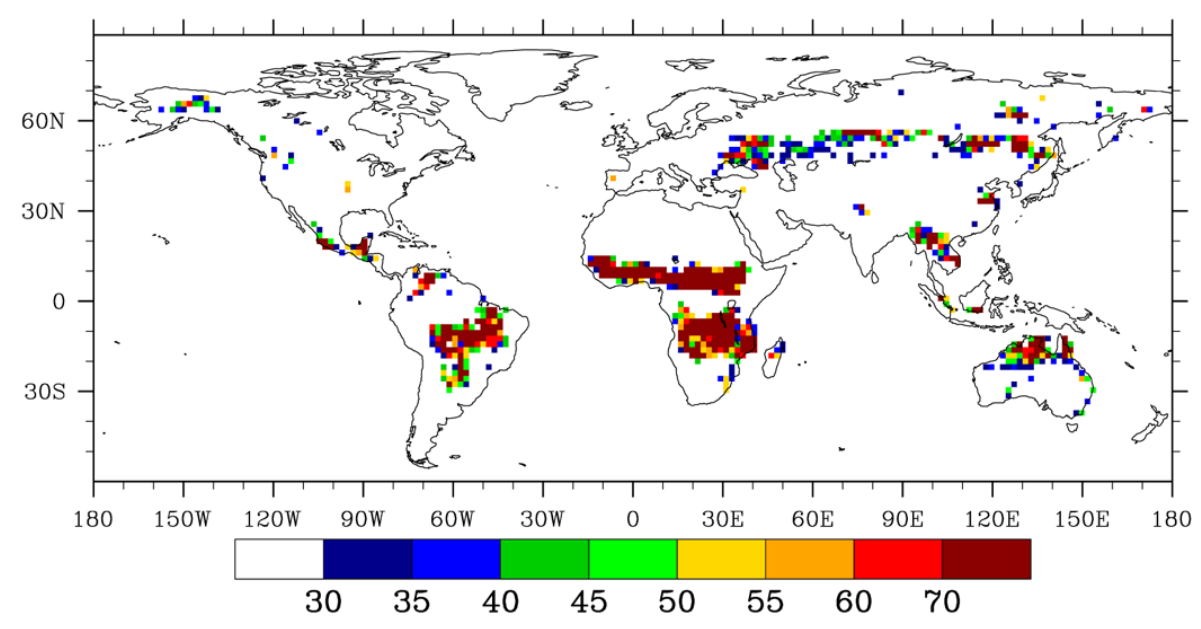

Fig. 1. MODIS active fire counts (count $\left.\left(1000 \mathrm{~km}^{2}\right)^{-1} \mathrm{mon}^{-1}\right)$ in the peak month of each year averaged over $2001-2009.1000 \mathrm{~km}^{2}$ are representative area set by CTEM-FIRE. Regions where value $>30$ count $\left(1000 \mathrm{~km}^{2}\right)^{-1} \mathrm{mon}^{-1}$ represent regions of more than 1 count $\left(1000 \mathrm{~km}^{2}\right)^{-1} \mathrm{day}^{-1}$.

$A_{\mathrm{b}}=N_{\mathrm{f}} a$,

where $N_{\mathrm{f}}$ (count (time step) ${ }^{-1}$ ) is fire counts in the grid cell; $a\left(\mathrm{~km}^{2}\right)$ is average fire spread area of a fire. The basic equation is different from those used by other process-based fire parameterizations of intermediate complexity. In Glob-FIRM (Thonicke et al., 2001), annual burned area is estimated by a non-linear function of fire season length, and fire season length is a function of fire occurrence probability in time steps. In CTEM-FIRE (Arora and Boer, 2005), daily burned area in a grid cell is calculated as the product of fire occurrence probability for a representative area $1000 \mathrm{~km}^{2}$, average burned area of a fire, and the grid-cell area divided by $1000 \mathrm{~km}^{2}$. Kloster et al. (2010) proposed a modified version of CTEM-FIRE by introducing anthropogenic ignition probability $(\leq 1.0)$ and suppression factor in the calculation of ignition probability $(\leq 1.0)$ and adding parameterization of deforestation fires. The modified version has the same basic function as CTEM-FIRE. Compared with Glob-FIRM, the new fire scheme can explicitly consider the impact of wind speed and fuel wetness on fire spread rate by the parameterization of $a$ (see Sect. 2.2). On the other hand, in the basic function of CTEM-FIRE, daily fire occurrence probability in a representative area of $1000 \mathrm{~km}^{2}$ is $\leq 1.0$ (Eq. 1 in Arora and Boer, 2005 and probability theory). In order to capture high burned area fraction in regions where fire counts $>1.0$ count $\left(1000 \mathrm{~km}^{2}\right)^{-1}$ day $^{-1}$ (Fig. 1), one may apply smaller representative area, shorter time-step length, or larger fire spread rate (quantitatively equivalent to simulate more than one fire during a time step). Using fire counts $N_{\mathrm{f}}$ eliminates this problem (fire counts have no mathematical upper limit), and does not require the assumption of representative area. In addition, unlike fire occurrence probability, fire counts $N_{\mathrm{f}}$ have
MODIS observations, so parameters about fire occurrence can be calibrated (see Appendices A and B).

The new fire parameterization comprises three parts: fire occurrence, fire spread, and fire impact (Fig. 2). The fire occurrence part estimates fire counts $N_{\mathrm{f}}$. The fire spread part estimates average fire spread area of a fire $a$. After burned area is calculated, the impacts of fire on vegetation components and structure, the carbon cycle, and trace gas and aerosol emissions are estimated in the third part. The first two parts have the same length of time step and can be updated hourly or daily. The third part can be updated hourly, daily, monthly, or annually. To generalize plant function to the global scale, DGVMs generally represent vegetation as plant functional types (PFTs) instead of species (Bonan et al., 2002). The PFTs used in the present study are listed in Table 1.

\subsection{Fire occurrence}

Whether a fire occurs due to an ignition source depends on three independent constraints: fuel load, fuel moisture, and human suppression (Schoennagel et al., 2004; Pechony and Shindell, 2009). Accordingly, fire counts $N_{\mathrm{f}}$ are taken as

$N_{\mathrm{f}}=N_{\mathrm{i}} f_{\mathrm{b}} f_{\mathrm{m}}\left(1-f_{\mathrm{s}}\right)$,

where $N_{\mathrm{i}}$ (count (time step) ${ }^{-1}$ ) is the number of ignition sources due to natural causes and human activities; $f_{\mathrm{b}}$ and $f_{\mathrm{m}}$ represent the availability and combustibility of fuel, respectively; $f_{\mathrm{s}}$ is the fraction of both anthropogenic and natural fires suppressed by human activities. The last three terms vary between 0.0 and 1.0 . 


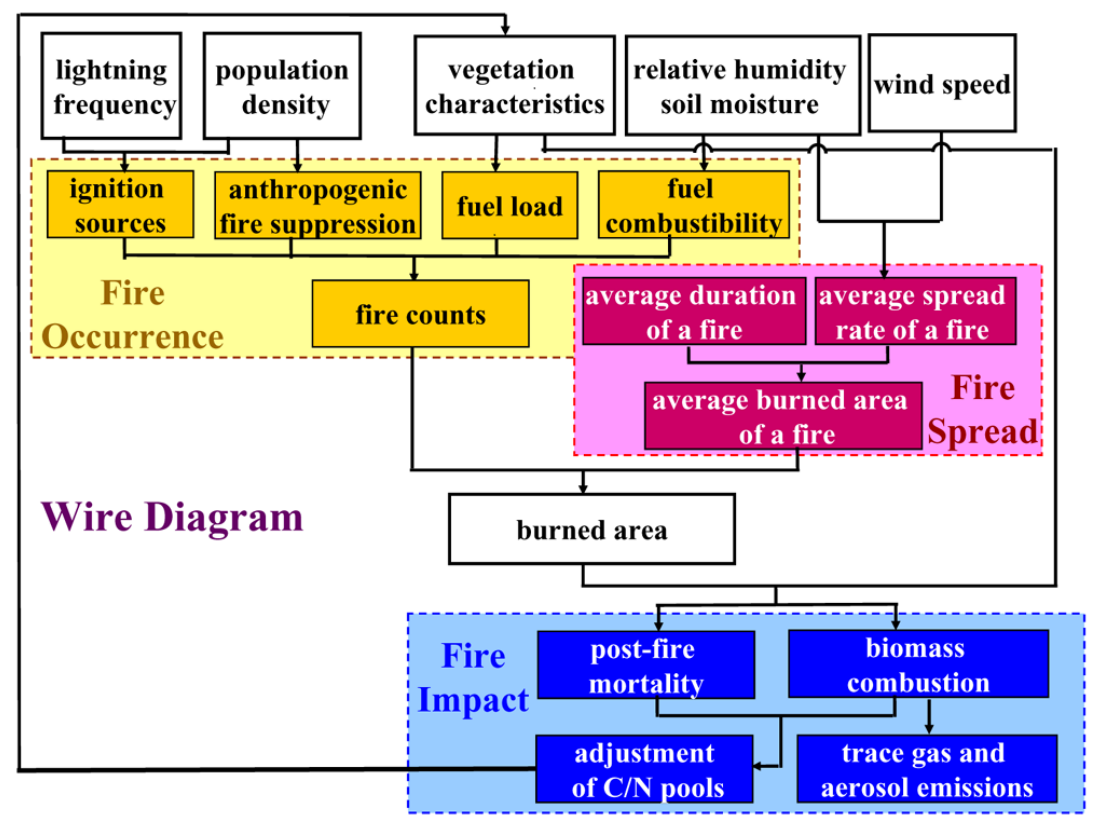

Fig. 2. Structure of the fire parameterization developed in the present study. Text boxes in yellow, red, and blue colors represent three parts in the fire module: fire occurrence, fire spread, and fire impact.

Table 1. Plant functional types (PFTs) used for parameter settings.

\begin{tabular}{ll}
\hline PFT & Abbreviation \\
\hline Trees & \\
Broadleaf Evergreen Tropical & BET Tropical \\
Broadleaf Deciduous Tropical & BDT Tropical \\
Broadleaf Evergreen Temperate & BET Temperate \\
Needleleaf Evergreen Temperate & NET Temperate \\
Broadleaf Deciduous Temperate & BDT Temperate \\
Needleleaf Evergreen Boreal & NET Boreal \\
Broadleaf Deciduous Boreal & BDT Boreal \\
\hline Grasses & \\
C4 & - \\
C3 Non-arctic & - \\
C3 Arctic & - \\
\hline Shrubs & \\
Broadleaf Deciduous Temperate & BDS Temperate \\
Broadleaf Deciduous Boreal & BDS Boreal \\
\hline
\end{tabular}

\subsubsection{Ignition counts $N_{\mathrm{i}}$}

$\left.N_{\mathrm{i}}(\text { count (time step })^{-1}\right)$ is given as

$N_{\mathrm{i}}=\left(I_{\mathrm{n}}+I_{\mathrm{a}}\right) A_{\mathrm{g}}$

where $I_{\mathrm{n}}\left(\text { count km}{ }^{-2} \text { (time step) }\right)^{-1}$ ) and $I_{\mathrm{a}}\left(\right.$ count $\mathrm{km}^{-2}$ (time step) ${ }^{-1}$ ) are the number of natural and anthropogenic ignitions per $\mathrm{km}^{2}$, respectively; $A_{\mathrm{g}}$ is the area of the grid cell $\left(\mathrm{km}^{2}\right)$.
The number of natural ignitions due to lightning discharges $I_{\mathrm{n}}$ is estimated by

$I_{\mathrm{n}}=\psi I_{1}$,

where $\psi=\frac{1}{5.16+2.16 \cos (3 \lambda)}$ is the cloud-to-ground lightning fraction and depends on the latitude $\lambda$ (Prentice and Mackerras, 1977); $I_{1}$ (flash $\mathrm{km}^{-2}$ (time step) ${ }^{-1}$ ) is the total lightning flashes. For an offline simulation, observations of $I_{1}$ can be obtained from the NASA LIS/OTD (ftp://ghrc.msfc.nasa. gov/pub/lis/climatology/LRTS/data/). Within an ESM, $I_{1}$ can be estimated from convective activity and cloud-top height simulated by the AGCM and a resolution-dependent calibration factor (Price and Rind, 1994).

Venevsky et al. (2002) proposed a scheme to parameterize the number of anthropogenic (intentional and accidental) ignitions as a nonlinear function of population density. The form of nonlinear function has been tested in peninsular Spain by Venevsky et al. (2002) and on a global scale by Pechony and Shindell (2009). In addition, the scheme is used in the modified version of CTEM-FIRE to estimate human ignition probability, which is assumed equal to 1 when population density is no less than 300 person $\mathrm{km}^{-2}$ (Kloster et al., 2010). Following Venevsky et al. (2002), the number of anthropogenic ignitions $I_{\mathrm{a}}$ is modeled as a monotonic increasing function of population density:

$I_{\mathrm{a}}=\frac{\alpha D_{\mathrm{p}} k\left(D_{\mathrm{p}}\right)}{n}$.

$\alpha=3.89 \times 10^{-3}$ (count person ${ }^{-1} \mathrm{mon}^{-1}$ ) is the number of potential ignition sources by a person per month, which is 
optimally estimated in Appendix A; $D_{\mathrm{p}}\left(\right.$ person $\left.\mathrm{km}^{-2}\right)$ is the population density; $k\left(D_{\mathrm{p}}\right)=6.8 D_{\mathrm{p}}^{-0.6}$ represents anthropogenic ignition potential varied with human population density $D_{\mathrm{p}}$, and reflects that people in scarcely populated regions interact more with natural ecosystems and thus potentially produce more ignitions; $n$ is the number of time steps in a month (mon (time step) ${ }^{-1}$ ).

\subsubsection{Fuel availability $f_{\mathrm{b}}$}

Fuel availability $f_{\mathrm{b}}$ is given as

$f_{\mathrm{b}}=\left\{\begin{array}{cc}0 & B_{\mathrm{ag}}<B_{\text {low }} \\ \frac{B_{\mathrm{ag}}-B_{\text {low }}}{B_{\text {up }}-B_{\text {low }}} & B_{\text {low }} \leq B_{\mathrm{ag}} \leq B_{\text {up }} \\ 1 & B_{\mathrm{ag}}>B_{\text {up }}\end{array}\right.$

where $B_{\mathrm{ag}}\left(\mathrm{g} \mathrm{C} \mathrm{m}^{-2}\right)$ is the aboveground biomass of combined leaf, stem and aboveground litter (leaf litter and woody debris) pools; $B_{\text {low }}\left(\mathrm{g} \mathrm{C} \mathrm{m}^{-2}\right)$ is the lower fuel threshold below which fire does not occur; $B_{\text {up }}\left(\mathrm{g} \mathrm{Cm}^{-2}\right)$ is the upper fuel threshold above which fire will occur if other conditions are favorable (Fig. 3a). Glob-FIRM (Thonicke et al., 2001) assumes $B_{\text {low }}=B_{\text {up }}=200 \mathrm{~g} \mathrm{C} \mathrm{m}^{-2}$ (where fuel is defined as aboveground litter). CTEM-FIRE (Arora and Boer, 2005) arbitrarily adopts $B_{\text {low }}=200 \mathrm{~g} \mathrm{C} \mathrm{m}^{-2}$ and $B_{\text {up }}=1000 \mathrm{~g} \mathrm{C} \mathrm{m}^{-2}$ (where fuel is defined as aboveground biomass) to reflect that fire becomes more likely to occur as fuel load increases until there is no longer a fuel load constraint. In this present study, $B_{\text {low }}=155 \mathrm{~g} \mathrm{C} \mathrm{m}^{-2}$ and $B_{\text {up }}=1050 \mathrm{~g} \mathrm{C} \mathrm{m}^{-2}$ are estimated by maximizing the correlation between observed and simulated fire counts at 24 grid cells in the United States based on remote sensing product, reanalysis data, and field data (Appendix A).

\subsubsection{Fuel combustibility $f_{\mathrm{m}}$}

Fuel combustibility $f_{\mathrm{m}}$ is estimated by

$f_{\mathrm{m}}=f_{\mathrm{RH}} f_{\theta}$,

where $f_{\mathrm{RH}}$ and $f_{\theta}$ represent the dependence of fuel combustibility on relative humidity RH (\%) and on surface soil wetness $\theta$, respectively. $f_{\mathrm{RH}}$ reflects the response of fuel combustibility to real-time climate conditions. Soil wetness has a memory of preceding precipitation and land surface water and heat status (Shinoda and Yamaguchi, 2003), so $f_{\theta}$ can reflect the response of fuel combustibility to preceding climate conditions.

$f_{\mathrm{RH}}$ is calculated by

$f_{\mathrm{b}}=\left\{\begin{array}{cc}1 & \mathrm{RH} \leq \mathrm{RH}_{\text {low }} \\ \frac{\mathrm{RH}_{\mathrm{up}}-\mathrm{RH}}{\mathrm{RH}_{\mathrm{up}}-\mathrm{RH}_{\text {low }}} & \mathrm{RH}_{\text {low }}<\mathrm{RH}<\mathrm{RH}_{\mathrm{up}} \\ 0 & \mathrm{RH} \geq \mathrm{RH}_{\mathrm{up}}\end{array}\right.$

and displayed in Fig. 3b. According to the China Forest Fire-Danger Weather Grading Criteria (Wang et al., 1995)
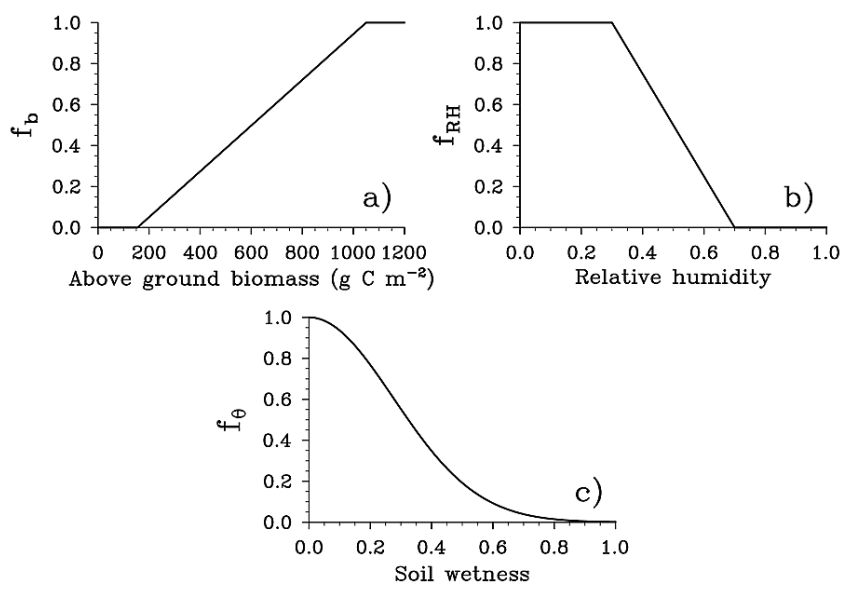

Fig. 3. Dependence of fire occurrence on (a) fuel availability $f_{\mathrm{b}}$, (b) relative humidity $f_{\mathrm{RH}}$, and (c) soil wetness $f_{\theta}$.

and Zhou and Lu (2009), fires will not occur and spread if $\mathrm{RH} \geq 70 \%$, and relative humidity will no longer be a constraint factor for fire occurrence and spread if $\mathrm{RH} \leq 30 \%$. Therefore, $\mathrm{RH}_{\text {low }}=30 \%$ and $\mathrm{RH}_{\text {up }}=70 \%$ are used as the lower and upper thresholds of relative humility in Eq. (8) and the dependence of fire spread rate in the downwind direction on relative humidity $C_{\mathrm{RH}}$ in Sect. 2.2.

$f_{\theta}$ is given by

$f_{\theta}=\exp \left[-\pi\left(\frac{\theta}{\theta_{\mathrm{e}}}\right)^{2}\right]$

and displayed in Fig. 3c, where $\theta$ is the soil wetness, defined as volumetric soil moisture relative to that at saturation; $\theta_{\mathrm{e}}$ is the extinction coefficient of soil wetness. Equation (9) assumes that the constraint of soil wetness on fire occurrence is higher than $95 \%$ when $\theta$ exceeds $\theta_{\mathrm{e}} \cdot \theta_{\mathrm{e}}=0.69$, which is derived from the MODIS Active Fire Count product (Giglio et al., 2006), the CLM 4.0 surface data (Lawrence and Chase, 2007, 2010), and the Climate Prediction Center (CPC) soil wetness product (Fan and van den Dool, 2004) (Appendix B).

Both $f_{\mathrm{RH}}$ and $f_{\theta}$ are important for estimating the fuel combustibility (Appendix A).

\subsubsection{Fraction of fires suppressed by humans $f_{\mathrm{s}}$}

Humans influence fires not only by adding ignition sources (intentionally and accidentally), but also by suppressing both anthropogenic and natural fires. In general, success of fire suppression depends on early fire detection, and fires are more likely detected in more densely populated regions ( $\mathrm{Pe}-$ chony and Shindell, 2009). Accordingly, the fraction of fires suppressed by humans is parameterized as a monotonic increasing function of population density:

$f_{\mathrm{s}}=\varepsilon_{1}-\varepsilon_{2} \exp \left(-0.025 D_{\mathrm{p}}\right)$

and is displayed in Fig. 4. The fractions of fires suppressed in densely populated regions (i.e. $D_{\mathrm{p}} \rightarrow+\infty$ ) and 
in uninhabited regions (i.e. $D_{\mathrm{p}}=0$ ) are estimated by $\varepsilon_{1}$ and $\varepsilon_{1}-\varepsilon_{2}$, respectively. In the present study, they are simply assumed to be $99 \%$ and $1 \%$; then $\varepsilon_{1}=0.99$ and $\varepsilon_{2}=0.98$. When global grid data relating to fire management policy and fire suppression capability (influenced by socio-economic conditions) become available, the coefficients $\varepsilon_{1}$ and $\varepsilon_{2}$ can be determined more accurately and vary in space and time. As shown in Fig. 4, the effect of fire suppression on anthropogenic ignitions starts at $\sim 1$ person $\mathrm{km}^{-2}$ and is stronger with increasing population density. The unsuppressed anthropogenic ignition frequency $I_{\mathrm{a}}\left(1-f_{\mathrm{s}}\right)$ peaks at a population density of 16 person $\mathrm{km}^{-2}$, then falls due to increased fire suppression, which is supported by the analysis of relationship between population density and the MODIS Active Fire Count in Southern Africa (Archibald et al., 2009) and on a global scale (Pechony and Shindell, 2009).

\subsection{Fire spread}

The post-fire region of a fire is typically taken to be elliptical in shape with the wind direction along the major axis and the point of ignition at one of the foci (Fig. 5). The ellipse shape of a fire is defined by length-to-breadth ratio:

$L_{\mathrm{B}}=\frac{l}{w}=\frac{\left(u_{\mathrm{p}}+u_{\mathrm{b}}\right)}{2 v}$

where $l(\mathrm{~m})$ and $w(\mathrm{~m})$ are the lengths of major and minor axes of the elliptical post-fire region; $u_{\mathrm{p}}\left(\mathrm{m} \mathrm{s}^{-1}\right)$ and $u_{\mathrm{b}}$ $\left(\mathrm{m} \mathrm{s}^{-1}\right)$ are fire spread rates in the downwind and upwind directions, respectively; $v\left(\mathrm{~m} \mathrm{~s}^{-1}\right)$ is the fire spread rate perpendicular to the wind direction. In the present study, we adopt

$L_{\mathrm{B}}=1.0+10.0[1-\exp (-0.06 W)]$

(Arora and Boer, 2005), where $W\left(\mathrm{~m} \mathrm{~s}^{-1}\right)$ is wind speed. According to mathematical properties of ellipses, the head-toback ratio $H_{\mathrm{B}}$ is

$H_{\mathrm{B}}=\frac{u_{\mathrm{p}}}{u_{\mathrm{b}}}=\frac{L_{\mathrm{B}}+\left(L_{\mathrm{B}}^{2}-1\right)^{0.5}}{L_{\mathrm{B}}-\left(L_{\mathrm{B}}^{2}-1\right)^{0.5}}$.

$L_{\mathrm{B}}$ and $H_{\mathrm{B}}$ are monotonic increasing functions with wind speed (Fig. 6a and b). The assumption of a globally constant $H_{\mathrm{B}}=5.0$ in CTEM-FIRE (Arora and Boer, 2005) is mostly inconsistent with Eq. (13) (Fig. 6b).

Fire spread rate in the downwind direction is represented as

$u_{\mathrm{p}}=u_{\max } C_{\mathrm{m}} g(W)$

(Arora and Boer, 2005), where $u_{\max }\left(\mathrm{m} \mathrm{s}^{-1}\right)$ is the average maximum fire spread rate in natural vegetation regions; $C_{m}$ and $g(W)$ represent the dependence of $u_{\mathrm{p}}$ on fuel wetness and wind speed $W$, respectively, and vary between 0.0 and 1.0. Arora and Boer (2005) proposed using a value on the low

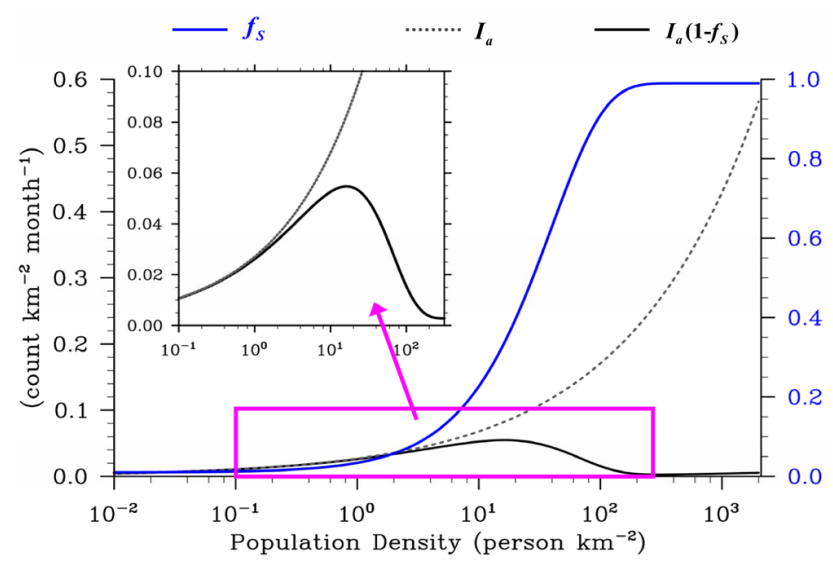

Fig. 4. Fraction of fires suppressed by humans $f_{\mathrm{s}}$ (blue solid), total anthropogenic ignitions $I_{\mathrm{a}}$ (count km ${ }^{-2} \mathrm{month}^{-1}$; gray dash), and unsuppressed anthropogenic ignitions $I_{\mathrm{a}}\left(1-f_{\mathrm{s}}\right)$ (count km $\mathrm{km}^{-2}$ month $^{-1}$; black solid) as functions of population density.

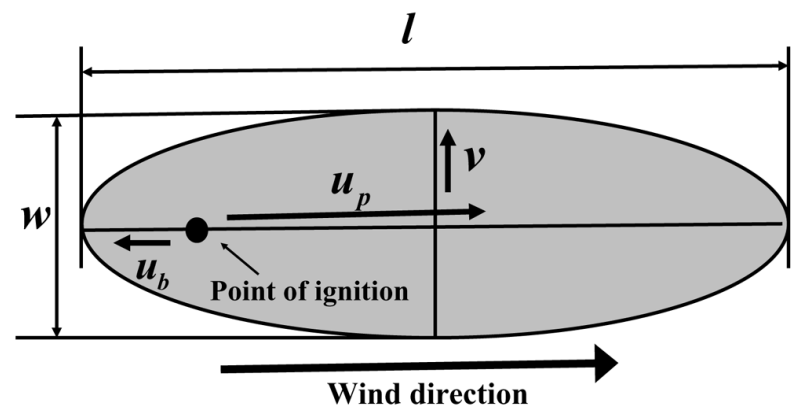

Fig. 5. Conceptual elliptical fire shape that is used to estimate the burned area with the wind direction along the major axis and the point of ignition at one of the foci.

side of observed fire spread rates to estimate $u_{\max }$ for scale transformation from individual fires to large-scale grid-cell average. Zhou and Lu (2009) and Cochrane and Ryan (2009) pointed out that surface fire is the most common fire type and, on average, spreads fastest in grasslands, and faster in shrublands than in forests; crown fires generally spread faster than surface fires and usually occur in coniferous forests due to the flammable resin in plant tissues and/or ladder fuels. Collectively, average maximum fire spread rate is set to be $0.2 \mathrm{~m} \mathrm{~s}^{-1}$ for grass PFTs, $0.17 \mathrm{~m} \mathrm{~s}^{-1}$ for shrub PFTs, $0.15 \mathrm{~m} \mathrm{~s}^{-1}$ for needleleaf tree PFTs, and $0.11 \mathrm{~m} \mathrm{~s}^{-1}$ for other tree PFTs rather than $0.13 \mathrm{~m} \mathrm{~s}^{-1}$ for all PFTs in CTEM-FIRE. All of these values are on the low side of observed fire spread rates in regions with different dominant vegetation types (Albini and Stocks, 1986; Riggan et al., 2004; Vega et al., 2006). $C_{\mathrm{m}}=C_{\beta} C_{\mathrm{RH}}$ is estimated by the dependence of $u_{\mathrm{p}}$ on root zone soil wetness $\left(C_{\beta}\right)$ and relative humidity $\left(C_{\mathrm{RH}}\right)$. Here, $\beta$ is a root zone soil moisture limitation function, and depends on the root distribution of PFTs and the soil water 

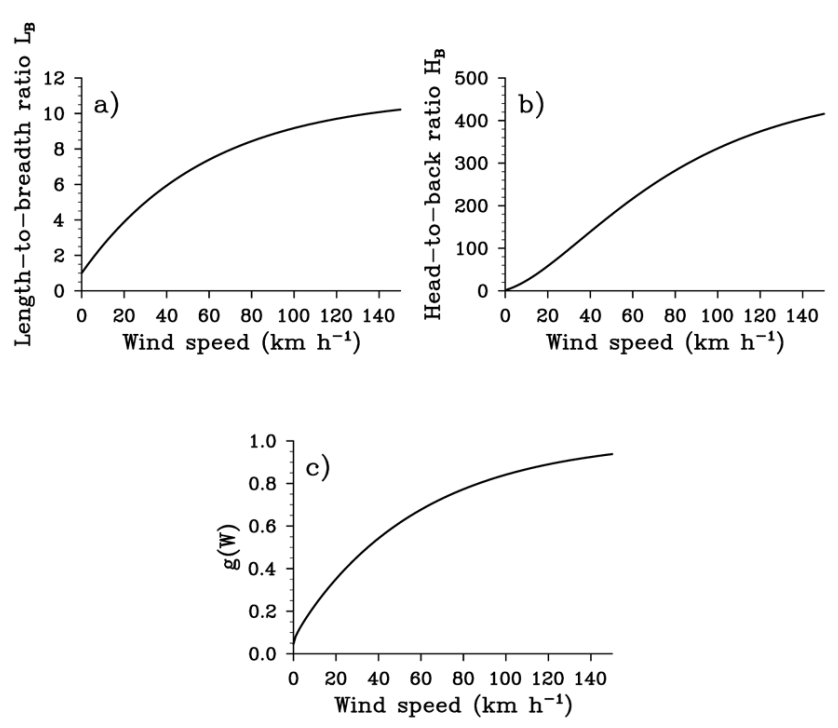

Fig. 6. (a) Length-to-breadth ratio $L_{\mathrm{B}}$, (b) head-to-back ratio $H_{\mathrm{B}}$, and (c) dependence of fire spread rate in the downwind direction on wind speed $g(W)$ as functions of wind speed.

potential of each soil layer (Levis et al., 2004; Oleson et al., 2010). Due to a lack of observations to calibrate function of $C_{\beta}$, we adopt a simple linear function, where $\beta_{\text {low }}=0.3$ and $\beta_{\text {up }}=0.7$ are applied as the lower and upper thresholds of root zone soil wetness, respectively. $C_{\beta}$, similar to a nonlinear function used in CTEM-FIRE (Arora and Boer, 2005), describes that fire spreads faster when the root zone is drier. $C_{\mathrm{RH}}$ is set equal to $f_{\mathrm{RH}}$, with the reasons given in Sect. 2.1.3.

Following Eq. (14), the fire spread rate perpendicular to the wind direction $v$ is:

$v=u_{\max } g(0) C_{\mathrm{m}}$

CTEM-FIRE (Arora and Boer, 2005) introduces a parameterization equation regarding $g(W)$ and assumes $g(0)=0.1$. In fact, $g(W)$ can be derived from Eqs. (11), (13), (14) and (15):

$g(W)=\frac{2 L_{\mathrm{B}}}{1+\frac{1}{H_{\mathrm{B}}}} g(0)$

(Fig. 6c). Fire spread rate in the downwind direction increases by $20 \%$ (obtained by Eqs. (14) and (16) as wind speed increases from 15 to $20 \mathrm{~km} \mathrm{~h}^{-1}$ ). This is broadly consistent with an increase of about $25 \%$ from the analysis of fire observations in the North Kimberley region of northwest Australia (Vigilante et al., 2004). Since $g(W)=1.0$, and $L_{\mathrm{B}}$ and $H_{\mathrm{B}}$ are at their maxima $L_{\mathrm{B}}^{\max }=11.0$ and $H_{\mathrm{B}}^{\max }=482.0$ when $W \rightarrow \infty, g(0)$ can be derived as

$g(0)=\frac{1+\frac{1}{H_{\mathrm{B}}^{\max }}}{2 L_{\mathrm{B}}^{\max }}=0.05$, which is half of the value assumed in CTEM-FIRE (Arora and Boer, 2005).

According to the area formula for an ellipse, average burned area of a fire with average fire duration $\tau$ (s) can be represented as

$a=\pi \frac{l}{2} \frac{w}{2} \times 10^{-6}=\frac{\pi u_{\mathrm{p}}^{2} \tau^{2}}{4 L_{\mathrm{B}}}\left(1+\frac{1}{H_{\mathrm{B}}}\right)^{2} \times 10^{-6}$

where $10^{-6}$ converts $\mathrm{m}^{2}$ to $\mathrm{km}^{2}$. Based on the MODIS active fire observations, Giglio et al. (2006) reported that 20012004 mean persistence of most fires in the world was around 1 day. In the absence of global grid data on barriers to fire (e.g. rivers, lakes, roads, firebreaks) and human fire-fighting efforts, average fire duration is simply taken to be 1 day in the present study. The average fire duration of 1 day is also used in CTEM-FIRE (Arora and Boer, 2005) and its modified version (Kloster et al. 2010) which assume fire extinguishing probability to be 0.5 , and is equal to the mathematical expectation of stochastic fire duration in Venevsky et al. (2002).

\subsection{Fire impact}

In the present study, as recommended by Fosberg et al. (1999), the impacts of fire on vegetation, carbon cycle, and atmospheric chemistry are considered.

\subsubsection{Fire impact on vegetation and the carbon cycle}

Fire affects vegetation and the carbon cycle through biomass combustion and post-fire mortality. Biomass combustion transfers carbon from combusted leaves, stems, roots and aboveground litter to the atmosphere; then post-fire mortality transfers carbon from leaves, stems and roots killed by fire to the litter pool.

Fire carbon emissions value of the $j$-th PFT, $\phi_{j}$ ( $\mathrm{gC}$ (time step $)^{-1}$ ), is

$\phi_{j}=A_{\mathrm{b}, j} \boldsymbol{C}_{\boldsymbol{j}} \cdot \boldsymbol{C} \boldsymbol{C}_{j}$

where $A_{\mathrm{b}, j}\left(\mathrm{~km}^{2} \text { (time step) }\right)^{-1}$ ) is burned area for the $j$-th PFT which is burned area in a grid cell weighted by fractional coverage of this PFT in vegetated region; $\boldsymbol{C}_{j}=\left(C_{\text {leaf }}, C_{\text {stem }}\right.$, $\left.C_{\text {root }}, C_{\mathrm{L}, \mathrm{ag}}\right)_{j}$ is a vector with carbon density for leaves, stems, roots, and aboveground litter $\left(\mathrm{g} \mathrm{C} \mathrm{km}^{-2}\right)$ as elements; $\boldsymbol{C} \boldsymbol{C}_{j}=\left(\mathrm{CC}_{\text {leaf }}, \mathrm{CC}_{\text {stem }}, \mathrm{CC}_{\text {root }}, \mathrm{CC}_{\mathrm{L}, \mathrm{ag}}\right)_{j}$ is corresponding combustion completeness factor vector (Table 2). Note that the fire impact time step can be longer than that of fire occurrence and spread; in this case, $A_{\mathrm{b}, j}$ is the accumulated burned area during the fire impact time step.

Parameterization of fire-related mortality varies with timestep length of estimation of fire impact on vegetation and carbon pools. In DGVMs that estimate the impact of fire annually, such as IBIS (Kucharik et al., 2000), LPJ (Sitch et al., 2003), CLM3-DGVM (Levis et al., 2004), SDGVM (Woodward and Lomas, 2004), ORCHIDEE (Krinner et al., 2005), 
Table 2. PFT-specific parameter values for combustion completeness factors for leaves $\left(\mathrm{CC}_{\text {leaf }}\right)$, stems $\left(\mathrm{CC}_{\text {stem }}\right)$, roots $\left(\mathrm{CC}_{\text {root }}\right)$ and aboveground litter $\left(\mathrm{CC}_{\mathrm{L}, \mathrm{ag}}\right)$; whole-plant mortality factor $\left(\xi_{j}\right)$; tissue-mortality factors for leaves $\left(M_{\text {leaf }}\right)$, stems $\left(M_{\text {stem }}\right)$ and roots $\left(M_{\text {root }}\right)$.

\begin{tabular}{lrrrrrrrr}
\hline PFT & $\mathrm{CC}_{\text {leaf }}$ & $\mathrm{CC}_{\text {stem }}$ & $\mathrm{CC}_{\text {root }}$ & $\mathrm{CC}_{\mathrm{L}, \mathrm{ag}}$ & $\xi_{j}$ & $M_{\text {leaf }}$ & $M_{\text {stem }}$ & $M_{\text {root }}$ \\
\hline BET Tropical & 0.70 & 0.15 & 0.00 & 0.50 & 0.10 & 0.70 & 0.60 & 0.10 \\
BDT Tropical & 0.70 & 0.10 & 0.00 & 0.45 & 0.07 & 0.70 & 0.55 & 0.07 \\
BET Temperate & 0.70 & 0.15 & 0.00 & 0.50 & 0.10 & 0.70 & 0.60 & 0.10 \\
NET Temperate & 0.75 & 0.20 & 0.00 & 0.55 & 0.13 & 0.75 & 0.65 & 0.13 \\
BDT Temperate & 0.70 & 0.10 & 0.00 & 0.45 & 0.07 & 0.70 & 0.55 & 0.07 \\
NET Boreal & 0.75 & 0.20 & 0.00 & 0.55 & 0.13 & 0.75 & 0.65 & 0.13 \\
BDT Boreal & 0.70 & 0.15 & 0.00 & 0.50 & 0.10 & 0.70 & 0.60 & 0.10 \\
C4 & 0.85 & - & 0.00 & 0.85 & 0.20 & 0.85 & - & 0.20 \\
C3 Non-arctic & 0.85 & - & 0.00 & 0.85 & 0.20 & 0.85 & - & 0.20 \\
C3 Arctic & 0.85 & - & 0.00 & 0.85 & 0.20 & 0.85 & - & 0.20 \\
BDS Temperate & 0.80 & 0.30 & 0.00 & 0.60 & 0.15 & 0.80 & 0.70 & 0.15 \\
BDS Boreal & 0.80 & 0.30 & 0.00 & 0.60 & 0.15 & 0.80 & 0.70 & 0.15 \\
\hline
\end{tabular}

SEIB-DGVM (Sato et al., 2007), and CoLM-DGVM (Dai et al., 2003; Chen, 2008), whole-plant mortality is calculated as an annual accumulation. For the $j$-th PFT, the number of individuals killed by fire per $\mathrm{km}^{2}$ (individual $\mathrm{km}^{-2}$ (time step $)^{-1}$ ) is given by

$P_{\text {disturb }, j}=\frac{A_{\mathrm{b}, j}}{f_{j} A_{\mathrm{g}}} P_{j} \xi_{j}$

where $f_{j}$ is the fraction coverage of the $j$-th PFT; $P_{j}$ (individual $\mathrm{km}^{-2}$ ) is the vegetation population density for the $j$-th PFT; $\xi_{j}$ is the whole-plant mortality factor (Table 2). All the uncombusted carbon in the individuals killed by fire is transferred to the litter pool. By contrast, in DGVMs that estimate the impact of fire hourly, daily or monthly, such as TRIFFID (Cox, 2001), CTEM (Arora, 2003), and CLM4.0CNDV (Oleson et al., 2010; Lawrence et al., 2011; Castillo et al., 2012), tissue mortality $\left(\mathrm{g} \mathrm{C} \mathrm{km}^{-2}\right.$ (time step) $\left.{ }^{-1}\right)$, which transfers a part of uncombusted leaf, stem and root carbon $C_{j}^{\prime}=\left(C_{\text {leaf }}\left(1-\mathrm{CC}_{\text {leaf }}\right), C_{\text {stem }}\left(1-\mathrm{CC}_{\text {stem }}\right), C_{\text {root }}(1-\right.$ $\left.\left.\mathrm{CC}_{\text {root }}\right)\right)\left(\mathrm{g} \mathrm{C} \mathrm{km}^{-2}\right)$ to the litter pool, is given by

$\Psi_{j}=\frac{A_{\mathrm{b}, j}}{f_{j} A_{\mathrm{g}}} \boldsymbol{C}_{j}^{\prime} \cdot \boldsymbol{M}_{j}$

where $\boldsymbol{M}_{j}=\left(M_{\text {leaf }}, M_{\text {stem }}, M_{\text {root }}\right)$ are tissue-mortality factors for leaves, stems and roots (Table 2).

Value ranges of combustion completeness factors and tissue-mortality factors in Table 2 are similar to those in earlier studies (Czimczik et al., 2003; Arora and Boer, 2005; van der Werf et al., 2010; Kloster et al., 2010; Rosa et al., 2011). For tree PFTs, the value range of combustion completeness factors is set to $0.70-0.75$ for leaves, $0.1-0.2$ for stems, zero for roots, and $0.45-0.55$ for aboveground litter (combined leaf litter and woody debris); tissue-mortality factors are set to $0.7-0.75$ for leaves, $0.55-0.65$ for stems, and $0.07-0.13$ for roots. For grass PFTs, the value of combustion completeness factors is set to 0.85 for leaves and aboveground litter (only leaf litter), and zero for roots; the value of tissue-mortality factors is set to 0.85 for leaves, and 0.2 for roots. For shrub PFTs whose physical characteristics are between those of trees and grasses, combustion completeness factors are set to 0.8 for leaves, 0.3 for stems, zero for roots, and 0.6 for aboveground litter (combined leaf litter and woody debris); the tissue-mortality factors are set to 0.8 for leaves, 0.7 for stems, and 0.15 for roots. In addition, we use whole-plant mortality factors of $0.07-0.13$ for tree PFTs, 0.2 for grass PFTs, and 0.15 for shrub PFTs, which are the same as the tissue-mortality factors for roots.

Specific values of combustion completeness factors and mortality factors for trees are PFT-dependent (Table 2). Needleleaf tree PFTs are given larger combustion completeness factors and mortality factors than other tree PFTs, because resin in their plant tissues and aboveground litter supports combustion and leads to more serious tissue-mortality or whole-plant mortality (Zhou and Lu, 2009). Conversely, BDT Tropical and BDT Temperate are assigned smaller stem combustion completeness factors, whole-plant mortality factors, and stem-mortality factors than other tree PFTs, to account for their thick bark, which resists combustion and damage (Hoffmann et al., 2003).

\subsubsection{Fire impact on emissions of trace gases and aerosols}

The estimation of trace gas and aerosol emissions offers an interface with atmospheric chemistry and aerosol models in ESMs. Emissions for trace gas and aerosol species $x$ and the $j$-th PFT, $E_{x, j}(\mathrm{~g} \text { specie (time step })^{-1}$ ), are given by

$E_{x, j}=\mathrm{EF}_{x, j} \frac{\phi_{j}}{[C]}$

(Andreae and Merlet, 2001), where $\mathrm{EF}_{x, j}$ $\left(\mathrm{g}\right.$ specie $\left.(\mathrm{kg} \mathrm{dm})^{-1}\right)$ is PFT-dependent emission factor, and $[C]=450 \mathrm{gC}(\mathrm{kg} \mathrm{dm})^{-1}$ is a conversion factor from dry matter to carbon. The emission factors of trace gases 
Table 3. PFT-specific emission factors $\left(\mathrm{g}\right.$ specie $(\mathrm{kg} \mathrm{dm})^{-1}$ ) for trace gases. $\mathrm{CO}_{2}$ : carbon dioxide, $\mathrm{CO}$ : carbon monoxide, $\mathrm{CH}_{4}$ : methane, NMHC: non-methane hydrocarbon, $\mathrm{H}_{2}$ : hydrogen gas, $\mathrm{NO}_{\mathrm{x}}$ : nitrogen oxides, $\mathrm{N}_{2} \mathrm{O}$ : nitrous oxide.

\begin{tabular}{lrrrrrrr}
\hline PFT & $\mathrm{CO}_{2}$ & $\mathrm{CO}$ & $\mathrm{CH}_{4}$ & $\mathrm{NMHC}$ & $\mathrm{H}_{2}$ & $\mathrm{NO}_{\mathrm{x}}$ & $\mathrm{N}_{2} \mathrm{O}$ \\
\hline BET Tropical & 1631 & 100 & 6.8 & 7.1 & 3.28 & 2.55 & 0.20 \\
BDT Tropical & 1654 & 64 & 2.4 & 3.7 & 0.98 & 2.49 & 0.20 \\
BET Temperate & 1576 & 106 & 4.8 & 5.7 & 1.80 & 3.24 & 0.26 \\
NET Temperate & 1576 & 106 & 4.8 & 5.7 & 1.80 & 3.24 & 0.26 \\
BDT Temperate & 1576 & 106 & 4.8 & 5.7 & 1.80 & 3.24 & 0.26 \\
NET Boreal & 1576 & 106 & 4.8 & 5.7 & 1.80 & 3.24 & 0.26 \\
BDT Boreal & 1576 & 106 & 4.8 & 5.7 & 1.80 & 3.24 & 0.26 \\
C4 & 1654 & 64 & 2.4 & 3.7 & 0.98 & 2.49 & 0.20 \\
C3 Non-arctic & 1576 & 106 & 4.8 & 5.7 & 1.80 & 3.24 & 0.26 \\
C3 Arctic & 1576 & 106 & 4.8 & 5.7 & 1.80 & 3.24 & 0.26 \\
BDS Temperate & 1576 & 106 & 4.8 & 5.7 & 1.80 & 3.24 & 0.26 \\
BDS Boreal & 1576 & 106 & 4.8 & 5.7 & 1.80 & 3.24 & 0.26 \\
\hline
\end{tabular}

(Table 3) and aerosols (Table 4) are based on field data in most fire-prone biomes, compiled by Andreae and Merlet (2001) and updated annually (M. O. Andreae, personal communication, 2011). Emission factors are scaled from biome-level to PFT-level using the method in Thonicke et al. $(2005,2010)$ which derived PFT emission factors of trace gases from Andreae and Merlet (2001) and M. O. Andreae (personal communication, 2003).

\section{Application in CLM-DGVM}

The Community Land Model version 3 with the Dynamic Global Vegetation Model (CLM3-DGVM) (Levis et al., 2004) is a widely used DGVM in current global change research. Land surface model CLM3, as a biogeophysics module, simulates water and heat states and gross primary production (GPP) used by the DGVM. In turn, the DGVM provides the CLM3 with information regarding vegetation composition, structure, and phenology. Three computational time steps are adopted in CLM3-DGVM: a sub-hourly (suggested range: 1200-3600 s) time step for biogeophysics and biogeochemistry processes; a daily time step for plant phenology; and an annual time step for vegetation dynamics processes. The vegetation dynamics processes comprise reproduction, turnover, mortality due to negative net primary production, allocation, competition, background mortality and mortality due to stress, fire disturbances, and survival and establishment processes. In the model, only natural vegetation is simulated, represented by the carbon stored in leaves, roots, sapwood and heartwood for woody PFTs and leaves and roots for grass PFTs.

In the present study, the CLM3-DGVM revised by Zeng et al. (2008) and Zeng (2010) (hereafter simply called CLMDGVM) is used as a platform to evaluate fire parameterizations. CLM-DGVM incorporates CLM3-DGVM with a submodel for temperate and boreal shrubs, as well as revi-
Table 4. PFT-specific emission factors $\left(\mathrm{g}\right.$ specie $\left.(\mathrm{kg} \mathrm{dm})^{-1}\right)$ for aerosols. $\mathrm{PM}_{2.5}$ : particles less than 2.5 micrometers in diameter, TPM: total particulate matter, TC: total carbon, OC: organic carbon, BC: black carbon.

\begin{tabular}{lrrrrr}
\hline PFT & PM $_{2.5}$ & TPM & TC & OC & BC \\
\hline BET Tropical & 8.3 & 11.8 & 6.0 & 4.3 & 0.56 \\
BDT Tropical & 5.2 & 8.5 & 3.4 & 3.2 & 0.47 \\
BET Temperate & 12.7 & 17.6 & 8.3 & 9.1 & 0.56 \\
NET Temperate & 12.7 & 17.6 & 8.3 & 9.1 & 0.56 \\
BDT Temperate & 12.7 & 17.6 & 8.3 & 9.1 & 0.56 \\
NET Boreal & 12.7 & 17.6 & 8.3 & 9.1 & 0.56 \\
BDT Boreal & 12.7 & 17.6 & 8.3 & 9.1 & 0.56 \\
C4 & 5.2 & 8.5 & 3.4 & 3.2 & 0.47 \\
C3 Non-arctic & 12.7 & 17.6 & 8.3 & 9.1 & 0.56 \\
C3 Arctic & 12.7 & 17.6 & 8.3 & 9.1 & 0.56 \\
BDS Temperate & 12.7 & 17.6 & 8.3 & 9.1 & 0.56 \\
BDS Boreal & 12.7 & 17.6 & 8.3 & 9.1 & 0.56 \\
\hline
\end{tabular}

sions to the "two-leaf" scheme used in the photosynthesis calculation and to the calculation of PFTs' fractional coverage. By adding temperate and boreal shrubs, the model now has 12 PFTs, including 7 tree PFTs, 3 grass PFTs, and 2 shrub PFTs (same as in Table 1). Zeng (2010) showed that CLM-DGVM reasonably simulated global vegetation distribution and dependence of vegetation distribution on climate conditions.

When the new fire parameterization is used in CLMDGVM, fire occurrence and fire spread parts are calculated at the same hourly time step as biogeophysical and biogeochemical processes. The fire impact part is updated annually with other vegetation dynamics processes, so the whole-plant mortality scheme in Eq. (20) is adopted in parameterization of vegetation mortality due to fire. In CLM-DGVM, stems are divided into sapwood and heartwood (the inside of sapwood) for woody PFTs; litter is divided into aboveground 
Table 5. Datasets used to drive CLM-DGVM and evaluate simulations.

\begin{tabular}{llll}
\hline Types & Variables & Sources & Resolutions \\
\hline Forcing data & $\begin{array}{l}\text { Precipitation } \\
\text { Surface air temperature }\end{array}$ & Qian et al. $(2006)$ & T62 $\left(\sim 1.875^{\circ}\right)$, \\
& $\begin{array}{l}\text { Wind speed } \\
\text { Specific humidity }\end{array}$ & & 3 -hourly \\
& $\begin{array}{l}\text { Air pressure } \\
\text { Downward solar radiation }\end{array}$ & & \\
& Relative humidity & NCEP/NCAR & $2.5^{\circ}, 6$-hourly \\
& & CRU & 10 min, monthly* \\
& Lightning frequency & NASA LIS/OTD v2.2 & $\begin{array}{l}2.5^{\circ}, 2 \text {-hourly* } \\
2.5^{\circ}, \text { daily }\end{array}$ \\
& & & $0.5^{\circ}, 5$-yr \\
& Population density & GPWv3, & 5 min, 10-yr \\
\hline Evaluation data & Burned area & HYDE v3.1 & $0.5^{\circ}$, monthly \\
& Fire emissions & GFED3 & \\
\hline Climatology data. & & &
\end{tabular}

litter and belowground litter. Accordingly, we set the combustion completeness factors of sapwood and heartwood to twice and 1/4 of those for stems, respectively; carbon in leaves, sapwood and heartwood of fire-killed individuals is transferred to the aboveground litter pool, while root carbon of fire-killed individuals is transferred to the belowground litter pool. Like most land surface models and DGVMs, CLMDGVM is a single-point model and assumes no energy and material to be exchanged between adjacent grid cells; hence, we do not consider fire propagations between grid cells. The simulations are run globally at T62 $\left(\sim 1.875^{\circ}\right)$ spatial horizontal resolution.

\section{Data}

Table 5 lists the data for simulation and evaluation. CLMDGVM with the new fire parameterization is spun-up for $880 \mathrm{yr}$ to approach an equilibrium state through cycling 55-yr (1950-2004) forcing data. The 55-yr forcing data are generated as follows. 1950-2004 precipitation, surface air temperature, wind speed, specific humidity, air pressure, and downward solar radiation data with $\mathrm{T} 62\left(\sim 1.875^{\circ}\right)$ and 3-hourly resolution are from Qian et al. (2006). 6-hourly $2.5^{\circ}$ reanalysis relative humidity data from the National Centers for Environmental Prediction/National Center for Atmospheric Research (NCEP/NCAR) are corrected by the Climate Research Unit (CRU) data using the method of Qian et al. (2006). Lightning data from May 1995 to December 2004 are derived from $2.5^{\circ}$ daily lightning time series $(4260 \times 144 \times 73)$ and 2 -h climatological lightning data $(365 \times 12 \times 144 \times 73)$ in the NASA LIS/OTD grid product v2.2 (ftp://ghrc.msfc.nasa.

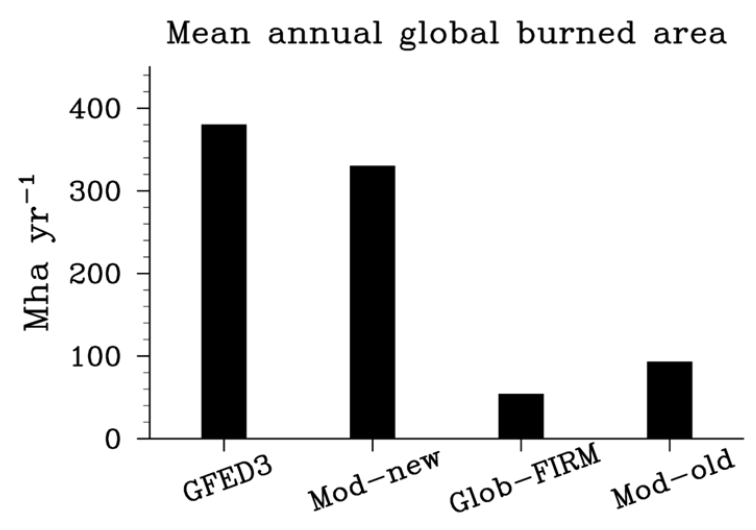

Fig. 7. 1997-2004 mean annual global burned area: GFED3 and CLM-DGVM simulations with the new fire parameterization (Modnew), the commonly used Glob-FIRM (Glob-FIRM), and the old fire parameterization in CLM-DGVM (Mod-old).

gov/pub/lis/climatology/LRTS/data/), while the 2-h climatological lightning data are used before May 1995. Population density data in $1990,1995,2000$, and 2005 at $0.5^{\circ}$ spatial resolution are provided by the GPWv3 (CIESIN, 2005). Prior to 1990 , 5 min decadal data from the HYDEv3.1 database are used (Klein Goldewijk et al., 2010). Finally, relative humidity, lightning frequency, and population density data are regridded to T62 and 3-hourly resolution to match the resolution of Qian's data and model resolution.

1997-2004 monthly burned area and fire emissions from the Global Fire Emission Database version 3 (GFED3) (Giglio et al., 2010; van der Werf et al., 2010) are used as benchmarks to assess the global performance of fire 


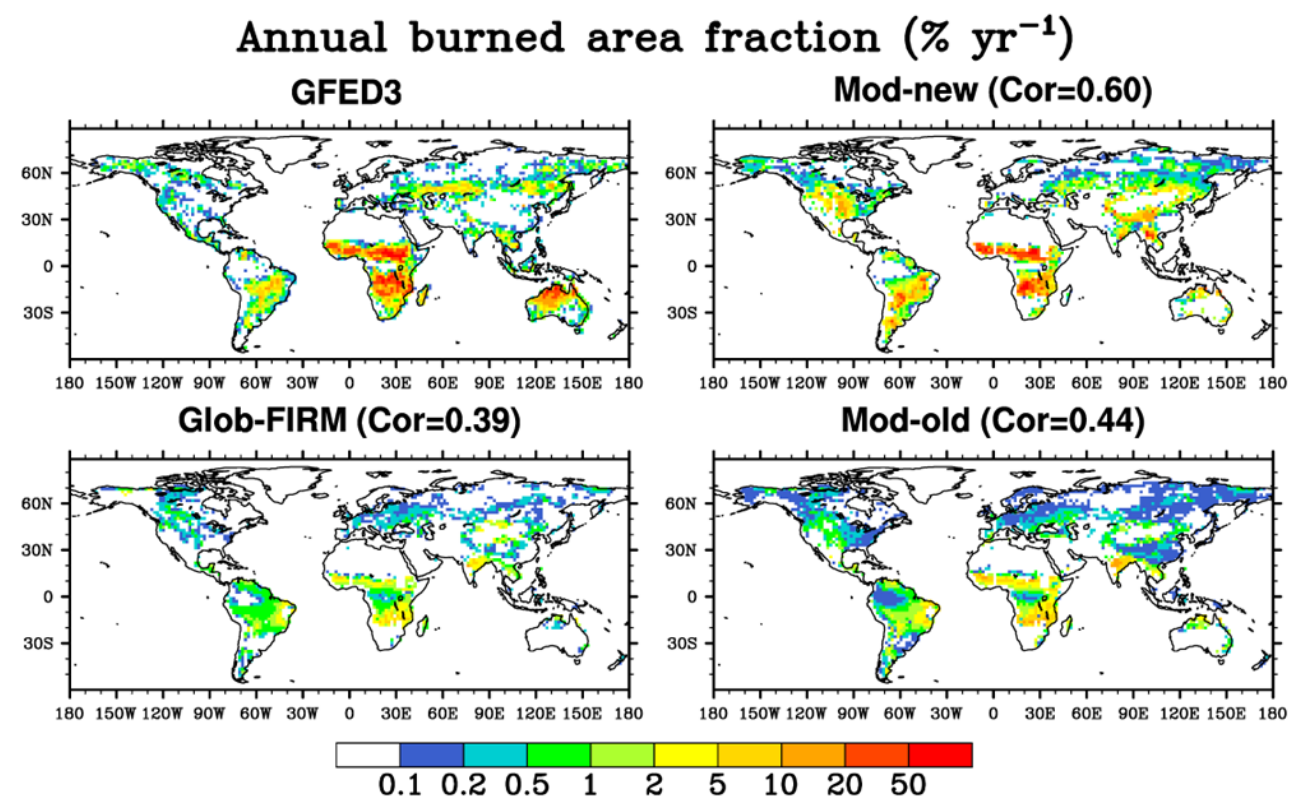

Fig. 8. Spatial distribution of annual burned area fraction averaged over 1997-2004 for GFED3 and CLM-DGVM with different fire parameterizations. The global spatial correlations (Cor) between observations and simulations are also given.

parameterizations. GFED3 burned area is a mixture of observations and satellite-based estimates, generated by 500 $\mathrm{m}$ MODIS burned area maps, active fire detections from multiple satellites, local regression, and regional regression trees (Giglio et al., 2010; L. Giglio, personal communication, 2012). GFED3 fire emissions are the output of a revised CASA biogeochemical model driven by GFED3 burned area, MODIS vegetation and land data, active fire detections from multiple satellites, weather observations, MODIS photosynthetically active radiation, and AVHRR NDVI data (van der Werf et al., 2010). GFED3 fire product represents the most comprehensive attempt to date to derive burned area and fire emissions from remote sensing data, and provides a suiTable benchmark for DGVM present-day fire simulations (Prentice et al., 2011).

\section{Results}

CLM-DGVM simulations with the fire parameterization introduced in Sect. 2 (Mod-new) are evaluated against the GFED3 fire product. The evaluation period is 1997-2004, which is the common period between GFED3 and the model forcing data. In addition, Mod-new is compared against CLM-DGVM simulations with the commonly used GlobFIRM fire parameterization (Glob-FIRM) and the old fire parameterization in CLM-DGVM (Mod-old). The two fire parameterization schemes are described in detail by Thonicke et al. (2001) and Levis et al. (2004), respectively.

\subsection{Burned area}

Figure 7 shows the GFED3 and simulated annual global burned area averaged over the time period 1997-2004. The mean annual global burned area of the new fire module is $330 \mathrm{Mha} \mathrm{yr}^{-1}$, close to the GFED3 (380 Mha yr ${ }^{-1}$ ). Relative to GFED3, both Glob-FIRM (54 Mha yr ${ }^{-1}$ ) and Modold $\left(93 \mathrm{Mha} \mathrm{yr}^{-1}\right)$ tend to underestimate the global burned area by at least $75 \%$. Furthermore, new fire parameterization reproduces the main feature of the global spatial distribution of burned area fraction (Fig. 8). It correctly captures the high burned area fraction for tropical savannas, the medium fraction for northern Eurasia, and the low fraction for deserts due to low fuel availability and for humid forests due to low fuel combustibility. Its simulation is closer to GFED3 than the commonly used Glob-FIRM and the old fire module, especially in the tropics. Global spatial correlation between GFED3 and simulations rises from Cor $=0.39$ for the Glob-FIRM and Cor $=0.44$ for the old fire module to $\mathrm{Cor}=0.60$ for the new one. In addition, using a biogeochemical model CLM-CN (Thornton et al., 2007), Kloster et al. (2010) tested the global performance of CTEM-FIRE and its modified version, and reported that simulated 1997-2004 mean annual global burned area and global spatial correlation were $300 \mathrm{Mha} \mathrm{yr}^{-1}$ and $\mathrm{Cor}=0.19$ for CTEM-FIRE and $182 \mathrm{Mha} \mathrm{yr}^{-1}$ and Cor $=0.52$ for its modified version. Compared with both, the Mod-new shows not only a more accurate simulation of global burned area but also higher global spatial correlation with GFED fire product. 


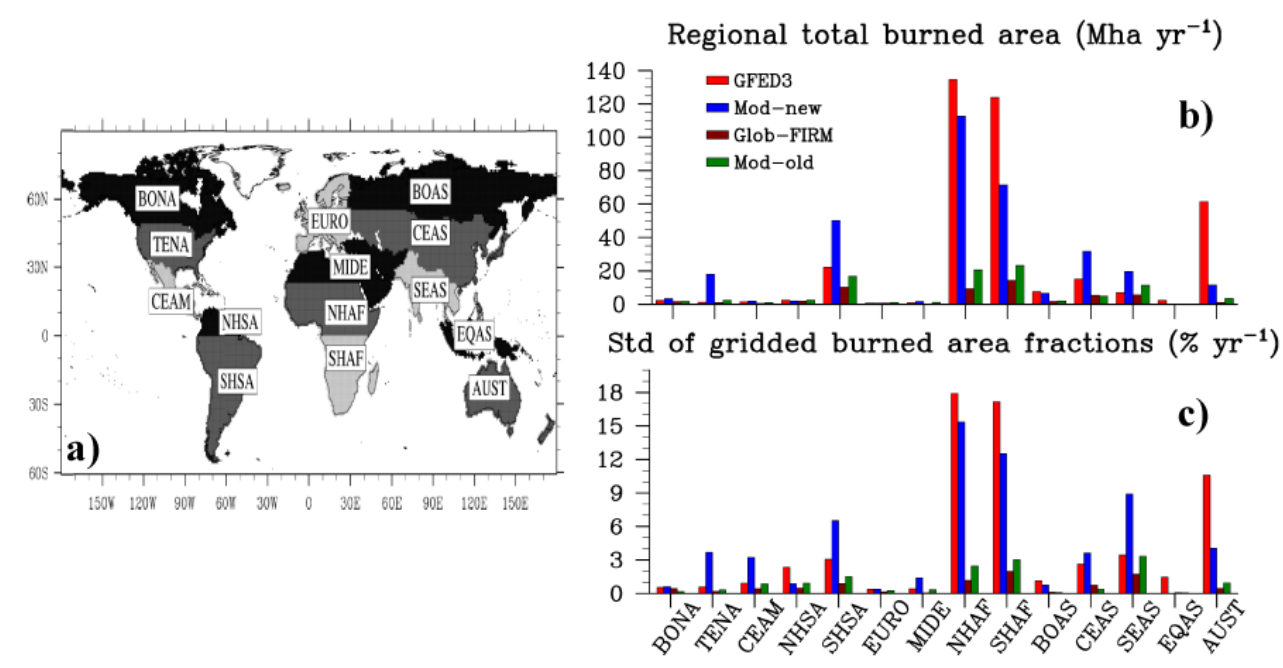

Fig. 9. (a) Map of 14 regions used in this study (left), after Giglio et al. (2006, 2010), van der Werf et al. (2006, 2010) and Kloster et al. (2010); (b) GFED3 and simulated regional annual burned area and (c) standard deviation of gridded burned area fraction in each region. BONA: Boreal North America; TENA: Temperate North America; CEAM: Central America; NHSA: Northern Hem. South America; SHSA: Southern Hem. South America; EURO: Europe; MIDE: Middle East; NHAF: Northern Hem. Africa; SHAF: Southern Hem. Africa; BOAS: Boreal Asia; CEAS: Central Asia; SEAS: South East Asia; EQAS: Equatorial Asia; AUST: Australia.

GFED3 and simulated regional burned area are shown in Fig. 9. The African continent contains the majority of global burned area. Based on GFED3, 1997-2004 average annual burned area is $134 \mathrm{Mha} \mathrm{yr}^{-1}$ for Northern Hemisphere Africa (NHAF) and $124 \mathrm{Mha} \mathrm{yr}^{-1}$ for Southern Hemisphere Africa (SHAF), respectively. All simulations have a low bias over Africa, but Mod-new (110 Mha $\mathrm{yr}^{-1}$, $70 \mathrm{Mha} \mathrm{yr}^{-1}$ ) captures the high burned area in Africa bet-

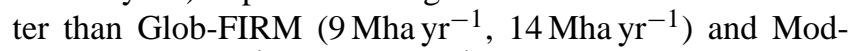
old (21 Mha yr ${ }^{-1}, 23 \mathrm{Mha} \mathrm{yr}^{-1}$ ) (Fig. 9b), as well as CLM-CN simulations with the CTEM-FIRE (74 Mha yr $-1,45 \mathrm{Mha} \mathrm{yr}^{-1}$ ) and its modified version (45 Mha yr ${ }^{-1}$,

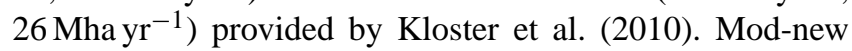
also captures the highest spread of burned area fraction in Africa (Fig. 9c). In addition, all CLM-DGVM simulations underestimate both the burned area and spread of burned area fraction over Australia (Fig. 9b and c), which is similar to the CTEM-FIRE and its modified version (Kloster et al., 2010).

Figure 10 shows the global burned area fractions of natural vegetation types (including trees, grasses, and shrubs). Here, global burned area fraction of a vegetation type means the fraction of area covered by the vegetation type that burned. Mod-new shows decreasing global burned area fraction in the order of grasses, trees, and shrubs as GFED3. It simulates global burned area fraction of trees accurately. The simulation errors for both grasses and shrubs relative to GFED3 are less than $30 \%$, though the Mod-new overestimates the global burned area fraction of grasses and underestimates that of shrubs. Mod-new is closer to GFED3 than GlobFIRM and Mod-old for all vegetation types. The Glob-FIRM and Mod-old underestimate global burned area fractions of

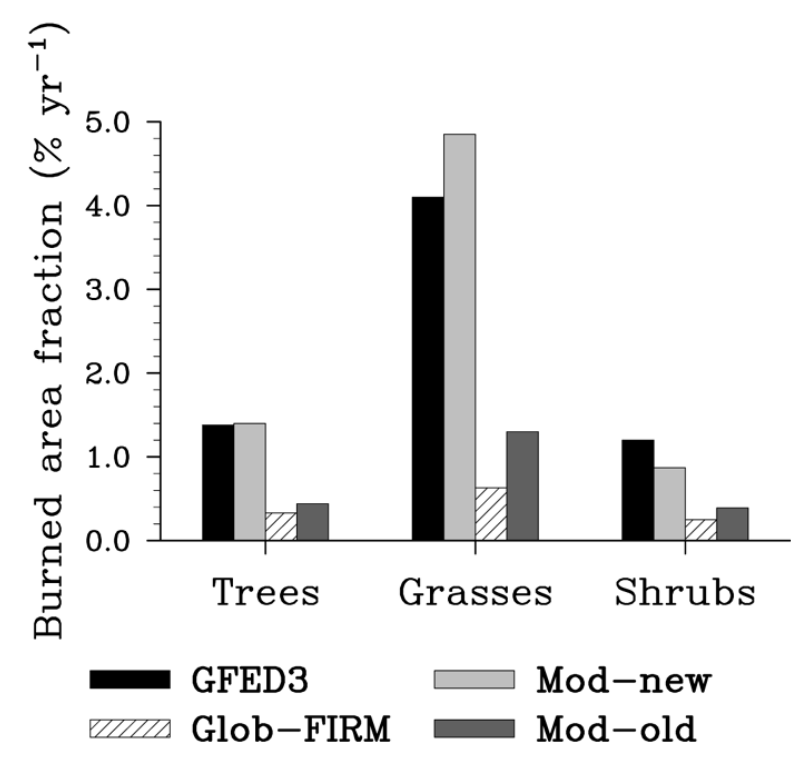

Fig. 10. 1997-2004 mean annual global burned area fraction of various natural vegetation types for GFED3 and CLM-DGVM simulations with different fire parameterizations.

natural vegetation types, and all of their errors are larger than $60 \%$ relative to GFED3.

Next, we test the simulated global spatial pattern of fire interannual variability by using standard deviation of annual burned area fraction (Fig. 11). The new fire parameterization and GFED3 show generally similar patterns, e.g., the high interannual variation over tropical savannas, the 


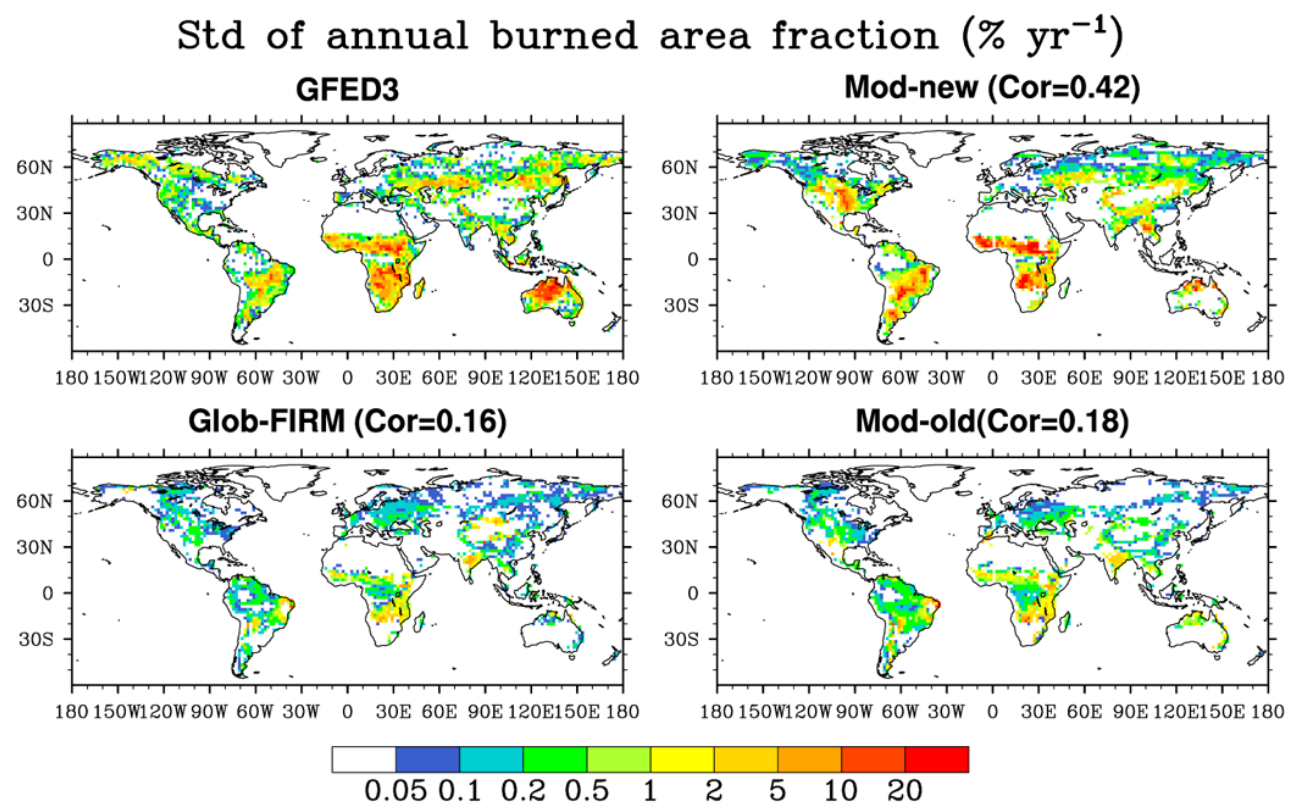

Fig. 11. Same as Fig. 8, but for standard deviation (Std) of annual burned area fraction, which is used as a spatially explicit measure of fire interannual variability.

medium variation over northern Eurasia, and the low variation over the deserts and humid forests. The global spatial correlation between GFED3 and simulations increases from Cor $=0.16$ for the Glob-FIRM and Cor $=0.18$ for the Mod-old to Cor $=0.42$ for the Mod-new. Figure 12 shows the GFED3 and simulated interannual variability of global burned area. Mod-new reproduces the peak in 1998 and yearto-year variation from 2000 to 2004. The temporal correlation between simulations and GFED 3 is 0.71 , higher than the Glob-FIRM (-0.16) and Mod-old (-0.01).

\subsection{Fire emissions}

Besides burned area, fire emissions are important variables to evaluate fire simulations. As shown in Fig. 13, the new fire module can reproduce the high carbon emissions in tropical savannas, the medium emissions in Northern Asia, and the low emissions in humid forests and deserts. Its global spatial correlation with GFED3 is 0.61 , higher than the GlobFIRM (Cor = 0.36) and the Mod-old (Cor =0.39). The global fire carbon emissions (GFCE) simulated by the new fire parameterization, averaged over $1997-2004$, are $2.0 \mathrm{Pg} \mathrm{Cyr}^{-1}$, closer to the GFED3 products $\left(\mathrm{GFCE}=2.1 \mathrm{Pg} \mathrm{C} \mathrm{yr}^{-1}\right)$ than the Glob-FIRM $\left(\mathrm{GFCE}=3.3 \mathrm{PgC} \mathrm{yr}^{-1}\right.$ ) and the Mod-old $\left(\mathrm{GFCE}=3.5 \mathrm{Pg} \mathrm{C} \mathrm{yr}^{-1}\right)$. The overestimation of fire carbon emissions will cause DGVMs with the Glob-FIRM and old fire parameterization to underestimate land carbon storage and overestimate net carbon exchanges between the global terrestrial biosphere and the atmosphere. Furthermore, the ratio of global annual carbon emissions to burned area reflects the combustion completeness of biomass in post-fire

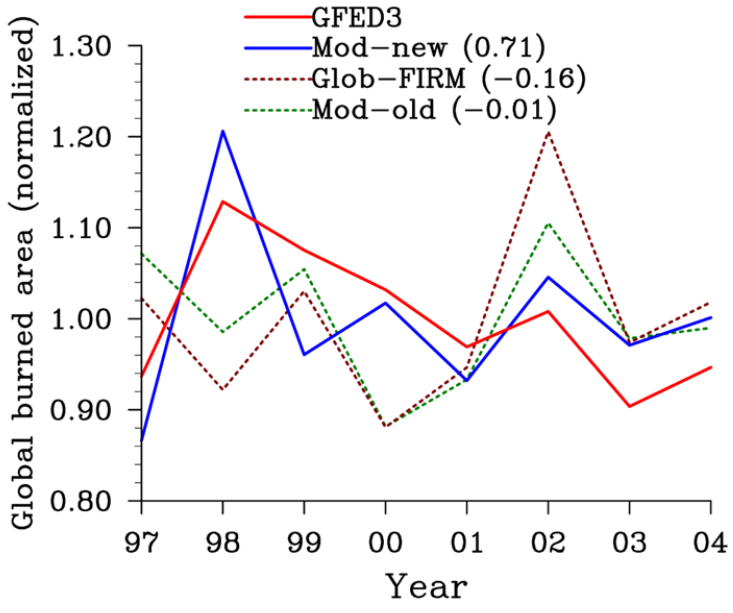

Fig. 12. Annual global burned area normalized by the mean for 1997-2004 from GFED3 and CLM-DGVM simulations with different fire parameterizations. The numbers in brackets denote temporal correlation between observations and simulations.

regions. The ratio for the Mod-new is 5.9 $\mathrm{Tg} \mathrm{C} \mathrm{Mha}^{-1}$, closer to GFED3 (5.5 $\mathrm{Tg} \mathrm{C} \mathrm{Mha}^{-1}$ ) than the other two fire modules (Glob-FIRM: 60.9 $\mathrm{Tg} \mathrm{C} \mathrm{Mha}^{-1}$, Mod-old: 37.9 $\mathrm{Tg} \mathrm{C} \mathrm{Mha}^{-1}$ ) (Table 6). The overestimation for the Glob-FIRM and the Mod-old is mainly because the observed low combustion completeness for stems and coarse woody debris is not accounted for in the two schemes. In addition, for 1997-2004, the new fire parameterization has higher global spatial correlation and a more accurate ratio of global annual carbon 


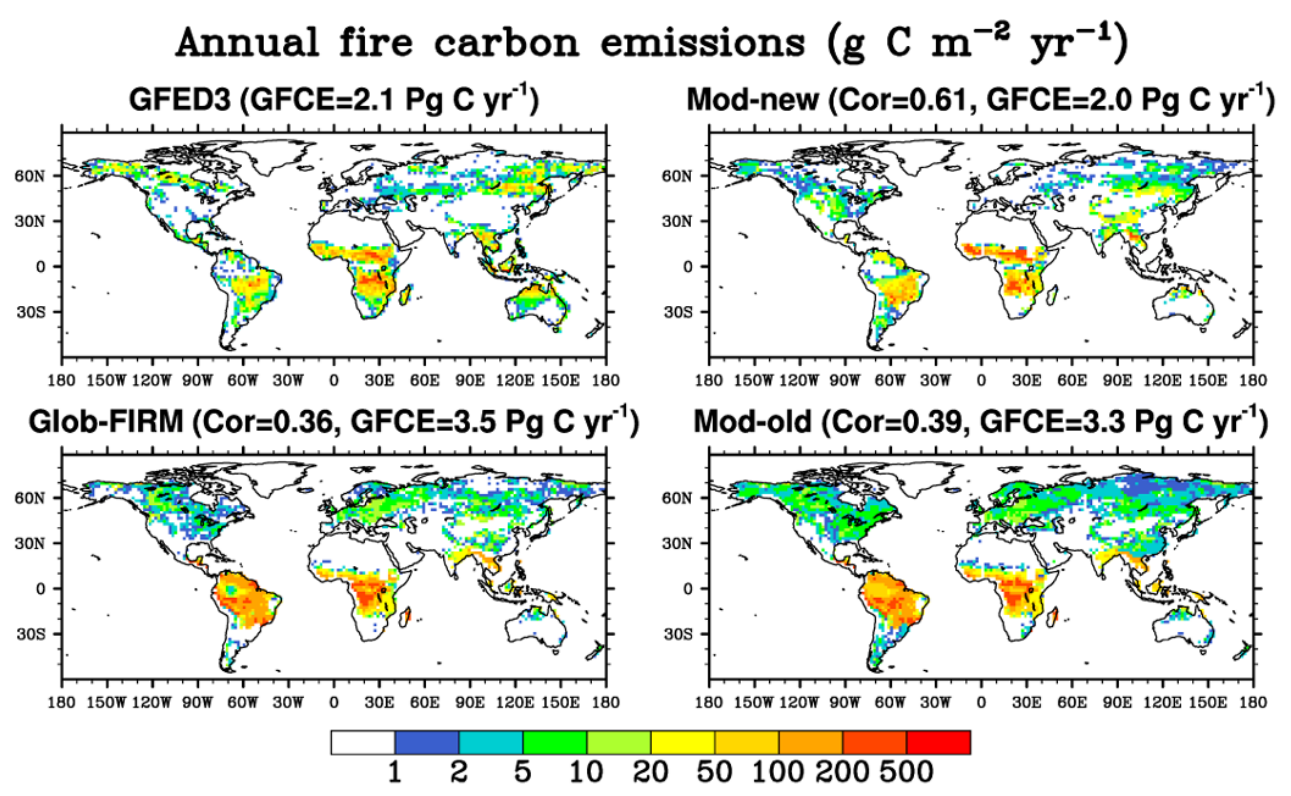

Fig. 13. Same as Fig. 8, but for annual fire carbon emissions. Besides global spatial correlation (Cor) between GFED3 and simulations, the GFED3 and simulated 1997-2004 mean annual global fire carbon emissions (GFCE) are also given.

Table 6. Ratio of 1997-2004 average global annual carbon emissions to burned area from GFED3 and simulations with various fire parameterization schemes.

\begin{tabular}{lr}
\hline Sources & Ratio $\left(\mathrm{Tg} \mathrm{Cha}^{-1}\right)$ \\
\hline GFED3 & 5.5 \\
Mod-new & 5.9 \\
Glob-FIRM & 60.9 \\
Mod-old & 37.9 \\
CTEM-FIRE $^{*}$ & 8.5 \\
Modified CTEM-FIRE $^{*}$ & 9.8 \\
\hline
\end{tabular}

${ }^{*}$ Kloster et al. (2010) tested global performance of the CTEM-FIRE and its modified version in a biogeochemical model CLM-CN (Thornton et al., 2007).

emissions to burned area than the CTEM-FIRE (Cor $=0.25$, ratio $\left.=8.5 \mathrm{TgC} \mathrm{Mha}^{-1}\right)$ and its modified version $(\mathrm{Cor}=0.45$, ratio $\left.=9.8 \mathrm{TgC} \mathrm{Mha}^{-1}\right)($ Kloster et al., 2010) when compared to GFED product.

Fire emissions contribute substantially to global budgets of trace gases and aerosols. The new fire parameterization introduces estimates of trace gas and aerosol emissions due to biomass burning as an interface with atmospheric chemistry and aerosol models in ESMs. As shown in Fig. 14, the simulated emissions of all types of trace gases and aerosols are in good agreement with the GFED3 products, and the average of relative errors is $7 \%$.

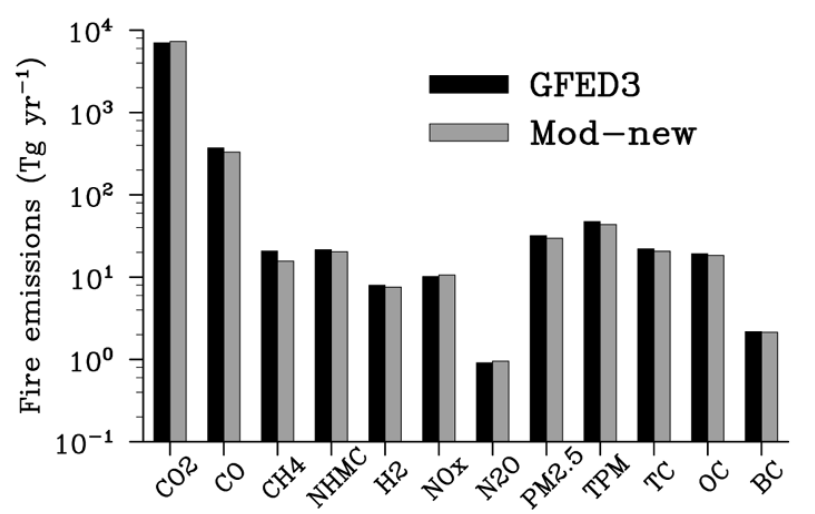

Fig. 14. 1997-2004 mean annual global emissions of trace gases and aerosols due to biomass burning from GFED3 fire product and CLM-DGVM simulation with the new fire parameterization.

\section{Conclusions and discussions}

In the present study, we have developed a process-based global fire parameterization scheme of intermediate complexity that fits the framework of DGVMs and is suitable for global change research. The fire parameterization comprises three parts: fire occurrence, fire spread, and fire impact. In the first part, the number of fires is determined by ignition counts due to anthropogenic and natural causes and three constraints: fuel load, fuel moisture, and human suppression. The anthropogenic ignition and suppression are explicitly considered as a function of population density. Fire counts rather than fire occurrence probability are estimated 
to improve the simulation accuracy on annual global burned area and global spatial distribution of burned area fraction. A sensitive test is performed using the new fire parameterization but estimating fire occurrence probability, i.e. assuming fire counts in a grid cell calculated in Eq. (2) no more than 1 count $^{-1}$. As shown in Fig. 15, high burned area fraction in tropical savanna region where fire occurs frequently cannot be caught well, which is the same as CTEM-FIRE and its modified version (Kloster et al., 2010). Simulated 1997-2004 annual global burned area decreases to $138 \mathrm{Mha} \mathrm{yr}^{-1}$ (Mod-

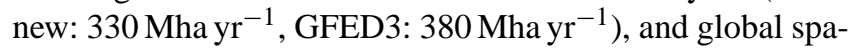
tial correlation (Cor) of simulated burned area fraction with GFED3 drops to 0.44 (Mod-new: Cor $=0.60$ ). In the second part, post-fire region is assumed to be elliptical in shape. Average burned area of a fire is determined by average fire spread rate and fire duration. We correct the calculations of $H_{\mathrm{B}}, g(W)$ and $g(0)$ in CTEM-FIRE using mathematical properties of ellipses and some mathematical derivations to make parameterization equations in this part self-consistent. After burned area is estimated by fire counts and average burned area of a fire, biomass combustion, post-fire mortality, adjustment of carbon pools, and trace gas and aerosol emissions are estimated in the fire impact part. Estimation of trace gas and aerosol emissions due to biomass burning is introduced to provide an interface with atmospheric chemistry and aerosol models in ESMs. Furthermore, the fire occurrence and spread parts can be updated hourly or daily, and fire impact part can be updated hourly, daily, monthly, or annually, which covers the scope of time-steps set by existing DGVMs. It makes the new fire parameterization easy to apply to various DGVMs.

CLM-DGVM is used as the model platform to assess the global performance of the new fire parameterization. Simulations are compared against the latest satellite-based GFED3 fire product for 1997-2004. Results show that simulated mean annual global burned area is $330 \mathrm{Mha} \mathrm{yr}^{-1}$ and global fire carbon emissions are $2.0 \mathrm{Pg} \mathrm{C} \mathrm{yr}^{-1}$, closer to the GFED3 (380 $\mathrm{Mha} \mathrm{yr}^{-1}, 2.1 \mathrm{Pg} \mathrm{C} \mathrm{yr}^{-1}$ ) than CLM-DGVM simulations with the commonly used Glob-FIRM fire parameterization (54 $\mathrm{Mha} \mathrm{yr}^{-1}, 3.5 \mathrm{PgC}^{-1}$ ) and the old fire module in CLM-DGVM (93 $\mathrm{Mha} \mathrm{yr}^{-1}, 3.3 \mathrm{PgC} \mathrm{yr}^{-1}$ ). The new fire parameterization also reasonably simulates global spatial distribution of annual burned area fraction and fire carbon emissions, shown to have higher global spatial correlation with GFED3 than the Glob-FIRM and the old one in burned area fraction (Mod-new: $\mathrm{Cor}=0.60$, Glob-FIRM: Cor $=0.39$, Mod-old: Cor $=0.44)$ and annual fire carbon emissions (Mod-new: Cor $=0.61$, Glob-FIRM: Cor $=0.36$, Mod-old: Cor $=0.39$ ). Compared with the 1997-2004 global evaluation results of the CTEM-FIRE and its modified version reported by Kloster et al. (2010), the new fire parameterization not only simulates global burned area and ratio of global fire carbon emission to burned area more accurately, but also shows higher global spatial correlation with GFED fire product on burned area fraction and fire carbon emis-

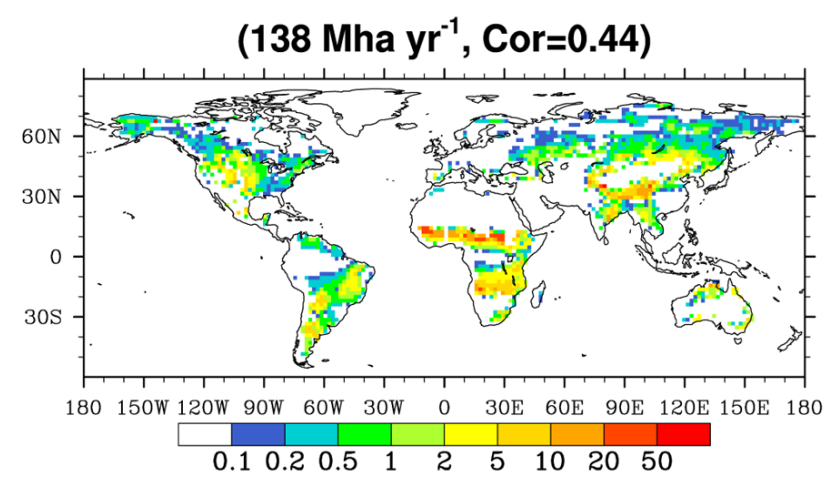

Fig. 15. Spatial distribution of 1997-2004 mean annual burned area fraction $\left(\% \mathrm{yr}^{-1}\right)$ simulated by CLM-DGVM, using the new fire parameterization but estimating fire occurrence probability (i.e. assuming fire counts calculated in Eq. (2) no more than 1 count $^{-1}$ ). Mean annual global burned area and global spatial correlation (Cor) are also given.

sions. Moreover, average error of the simulated global fire emissions of various trace gases and aerosols is $7 \%$ relative to GFED3, and can provide skillful estimates of fire emissions to atmospheric chemistry and aerosol models in ESMs. Results suggest that the new fire parameterization may improve the performance of ESMs and help to quantify firevegetation-climate interactions on a global scale and from an Earth system perspective.

Future development regarding design and evaluation of the fire parameterization are in three aspects. First, representation of anthropogenic impacts on fires needs further improvement. In the new fire parameterization, only population density is used to parameterize anthropogenic ignitions and suppression. In reality, fire management policy and fire suppression capability, for example, are also important (Chuvieco et al., 2008; Pechony and Shindell, 2009) but have not been included yet. Moreover, there are different kinds of fires. Agricultural fires are found to account for 8-11\% of 2001-2003 annual global fire counts (Korontzi et al., 2006), and $4.7 \%$ and 3\% of 2001-2009 annual global burned area and fire carbon emissions (van der Werf et al., 2010). Our fire parameterization and the Glob-FIRM (Thonicke et al., 2001) do not model them due to the absence of crop PFTs in the modelplatforms CLM-DGVM and LPJ, which leads to inaccurate fire simulations over real cropland. For example, burned area and fire carbon emissions over the cropland are overestimated in America (Figs. 8 and 13). Other global fire models with cropland information assume no fires in cropland (Arora and Boer, 2005; Thonicke et al., 2010; Kloster et al., 2010; Prentice et al., 2011) and hence underestimate burned area and fire carbon emissions over cropland. Peat fires and deforestation fires are important sources for fire carbon emissions (van der Werf et al., 2010). So far, no global fire model includes peat fires. In the present study, this could explain the underestimation of burned area and especially fire carbon 
emissions in Indonesia and boreal peatlands (Figs. 8 and 13). In all existing global fire models, only modified CTEM-FIRE (Kloster et al., 2010) has tried to model deforestation fires in a biogeochemical model with land use change data. In Kloster et al. (2010), fires in a grid cell are set to be the sum of deforestation fires and fires due to natural and anthropogenic (intentional and accidental) ignitions. Second, average fire duration is taken as 1 day in the present study. However, fire duration varies with climate conditions, vegetation and land characteristics, and human activities, which will be quantified when global or regional fire duration data with high temporal resolution (e.g. hourly) become available. Third, the new fire parameterization's simulation of fire seasonality needs to be evaluated using DGVMs, which simulate the seasonality of above-ground biomass and estimate fire impact hourly, daily or monthly. Vegetation dynamics processes in most existing DGVMs, including CLM-DGVM, are updated annually. Accordingly, impact of fires on aboveground biomass is estimated at the end of year, and aboveground biomass during a year is constant. Therefore, when using CLM-DGVM as the test platform of the new fire parameterization, impact of fuel-load variability (including that caused by earlier fires) during a year on fire seasonality cannot be captured, and fire seasonality is simulated inaccurately for regions where fires are limited by fuel availability.

\section{Appendix A}

In this appendix, three parameters in the fire occurrence part are calibrated. They are the number of potential ignition sources produced by one person $\alpha$ in Eq. (5), and the lower and upper fuel thresholds $B_{\text {low }}$ and $B_{\text {up }}$ in Eq. (6). All the three parameters have not estimated objectively in earlier studies. Also, we check whether making fuel combustibility dependent on both relative humidity $f_{\mathrm{RH}}$ and soil wetness $f_{\theta}$ in Eq. (7) is redundant.

The six datasets used here include (i) the MODIS Active Fire Count product (Giglio et al., 2006), (ii) relative humidity data and (iii) population density data introduced in Sect. 4, (iv) the CPC soil moisture product (Fan and van den Dool, 2004), (v) the FCCS above-ground biomass dataset that just covers the United States (McKenzie et al., 2007; Ottmar et al., 2007; Spracklen et al., 2009, http://www.fs.fed.us/pnw/ fera/fccs), and (vi) vegetation fractional cover data from the CLM4.0 surface data (Lawrence and Chase, 2007, 2010). The common period for the first four datasets is 2001-2004, and last two datasets describe present fuel loading and vegetation characteristics. All the datasets are interpolated to T62 spatial resolution.

Twenty-four grid cells over the United States are selected, satisfying three conditions. First, the fraction of croplands is less than $5 \%$ and natural vegetation is present, given that fires in croplands and natural vegetation regions behave dif- ferently and the latter is the focus of the present study (Table 1). Second, the grid cell contains no missing data. Third, monthly mean ignition counts due to lightning are negligible ( $I_{\mathrm{a}} \leq 5 \%$ of MODIS fire counts) to simplify the optimal estimation of parameters (see below).

At the selected grid cells, the number of fires in a time step is

$N_{\mathrm{f}}=N_{\mathrm{i}} f_{\mathrm{b}} f_{\mathrm{m}}\left(1-f_{\mathrm{s}}\right)=\frac{\alpha D_{\mathrm{p}} k\left(D_{\mathrm{p}}\right)}{n} A_{\mathrm{g}} f_{\mathrm{b}} f_{\mathrm{m}}\left(1-f_{\mathrm{s}}\right)$.

Using the constrained optimization method in MATLAB Optimization Toolbox, the correlation between simulated and observed 2001-2004 annual fire counts is highest (0.83) when $B_{\text {low }}=155 \mathrm{~g} \mathrm{C} \mathrm{m}^{-2}$ and $B_{\text {up }}=1050 \mathrm{~g} \mathrm{C} \mathrm{m}^{-2}$. The constant $\alpha$ can then be expressed as

$$
\begin{aligned}
& \alpha=\frac{\operatorname{avg}\left(N_{\mathrm{f}, \text { MODIS }}\right) n}{\operatorname{avg}\left(D_{\mathrm{p}} k\left(D_{\mathrm{p}}\right) A_{\mathrm{g}} f_{\mathrm{b}} f_{\mathrm{m}}\left(1-f_{\mathrm{s}}\right)\right)} \\
& =3.89 \times 10^{-3} \text { (count person }{ }^{-1} \text { mon }^{-1} \text { ). }
\end{aligned}
$$

In addition, based on the sample, we also check the redundancy of parameterizations about fuel combustibility on relative humidity $f_{\mathrm{RH}}$ and soil wetness $f_{\theta}$ in Eq. (7). If we remove the term $f_{\mathrm{RH}}$, the correlation between simulated and observed 2001-2004 annual fire counts drops from 0.83 to 0.73. If the term $f_{\theta}$ is removed, the correlation drops from 0.83 to 0.77 . We conclude that both $f_{\mathrm{RH}}$ and $f_{\theta}$ contribute to reasonable estimates of fuel combustibility.

\section{Appendix B}

Based on Eq. (9), the constraint of soil wetness on fire occurrence is higher than $95 \%$ (i.e. $f_{\theta}<0.05$ ) when soil wetness $\theta$ exceeds the extinction coefficient of soil wetness $\theta_{\mathrm{e}}$. The datasets used to calibrate $\theta_{\mathrm{e}}$ include the MODIS monthly active fire count product (Giglio et al., 2006), the CPC monthly soil wetness product (Fan and van den Dool, 2004), and the PFT fraction coverage data from the CLM 4.0 surface data (Lawrence and Chase, 2007, 2010). All data are interpolated to grid cells at T62 spatial resolution. The common period of the first two datasets is 2001-2009, and vegetation data from CLM 4.0 surface data describe present vegetation composition and structure.

The calibration procedure of parameter $\theta_{\mathrm{e}}$ is as follows. First, a sample is selected from the above three global datasets. It comprises the soil wetness data in grid cells and months from 2001 to 2009 that meet two conditions: (i) the fraction of croplands is less than $5 \%$ with reasons introduced in Appendix A, and the fractional coverage of natural vegetation is larger than $50 \%$; (ii) there is at least one fire in the grid cell in the month. The sample size is 37677 . Then, $\theta_{\mathrm{e}}=0.69$ is estimated using the upper 95th quantile of the sample. 
Appendix C

Table C1 List of model variables.

\begin{tabular}{|c|c|c|}
\hline Variable & Description & Unit \\
\hline$a$ & Average post-fire area of a fire & $\mathrm{km}^{2}$ \\
\hline$A_{\mathrm{b}}$ & Burned area per time step & $\mathrm{km}^{2}$ (time step) $)^{-1}$ \\
\hline$A_{\mathrm{b}, j}$ & Burned area of the $j$-th PFT & $\mathrm{km}^{2}$ (time step) $)^{-1}$ \\
\hline$A_{\mathrm{g}}$ & Area of grid cell & $\mathrm{km}^{2}$ \\
\hline$B_{\mathrm{ag}}$ & Aboveground biomass & $\mathrm{g} \mathrm{C} \mathrm{m}^{-2}$ \\
\hline$B_{\text {low }}$ & Lower fuel threshold & $\mathrm{g} \mathrm{C} \mathrm{m}^{-2}$ \\
\hline$B_{\text {up }}$ & Upper fuel threshold & $\mathrm{g} \mathrm{C} \mathrm{m}^{-2}$ \\
\hline$C_{j}$ & Carbon density vector for the $j$-th PFT & $\mathrm{g} \mathrm{C} \mathrm{km}^{-2}$ \\
\hline$C_{j}^{\prime}$ & $\begin{array}{l}\text { Carbon density vector after combustion } \\
\text { for the } j \text {-th PFT }\end{array}$ & $\mathrm{g} \mathrm{C} \mathrm{km}^{-2}$ \\
\hline$C C_{j}$ & $\begin{array}{l}\text { Combustion completeness factor vector } \\
\text { for the } j \text {-th PFT }\end{array}$ & - \\
\hline$C_{\mathrm{m}}$ & Dependence of $u_{p}$ on fuel wetness & - \\
\hline$C_{\mathrm{RH}}$ & Dependence of $u_{p}$ on $\mathrm{RH}$ & - \\
\hline$C_{\beta}$ & Dependence of $u_{p}$ on $\beta$ & - \\
\hline$D_{\mathrm{p}}$ & Population density & person $\mathrm{km}^{-2}$ \\
\hline$E_{x, j}$ & Emissions for species $x$ and $j$-th PFT & g specie (time step) $)^{-1}$ \\
\hline $\mathrm{EF}_{x, j}$ & Emission factor for species $x$ and $j$-th PFT & $\mathrm{g}$ specie $(\mathrm{kg} \mathrm{dm})^{-1}$ \\
\hline$f_{\mathrm{b}}$ & Fuel availability factor & - \\
\hline$f_{j}$ & Fuel combustibility factor & - \\
\hline$f_{\mathrm{m}}$ & Fraction coverage of the $j$-th PFT & - \\
\hline$f_{\mathrm{RH}}$ & Dependence of fuel combustibility on RH & - \\
\hline$f_{\mathrm{s}}$ & Fraction of fires suppressed by humans & - \\
\hline$f_{\theta}$ & Dependence of fuel combustibility on $\theta$ & - \\
\hline$g(W)$ & Dependence of $u_{\mathrm{p}}$ on $W$ & - \\
\hline$H_{\mathrm{B}}$ & Head-to-back ratio & 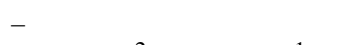 \\
\hline$I_{\mathrm{a}}$ & Anthropogenic ignition counts & count $\mathrm{km}^{-2}{\text { (time step })^{-1}}$ \\
\hline$I_{1}$ & Total lightning flashes & flash $\mathrm{km}^{-2}(\text { time step })^{-1}$ \\
\hline$I_{\mathrm{n}}$ & Natural ignition counts due to lightning & count $\mathrm{km}^{-2}(\text { time step })^{-1}$ \\
\hline$k\left(D_{\mathrm{p}}\right)$ & Anthropogenic ignition potential & - \\
\hline$l$ & Length of major axis of elliptical post-fire region & $\mathrm{m}$ \\
\hline$L_{\mathrm{B}}$ & Length-to-breadth ratio & - \\
\hline $\boldsymbol{M}_{j}$ & Tissue-mortality factor vector for the $j$-th PFT & - \\
\hline$n$ & The number of time steps in a month & mon (time step) $)^{-1}$ \\
\hline$N_{\mathrm{f}}$ & Fire counts per time step & count (time step) $)^{-1}$ \\
\hline$N_{\mathrm{i}}$ & Ignition counts per time step & count (time step) \\
\hline$P_{\text {disturb }, j}$ & Fire-killed individuals for the $j$-th PFT per $\mathrm{km}^{2}$ & individual $\mathrm{km}^{-2}$ (time step $)^{-1}$ \\
\hline & Vegetation population density for the $j$-th PFT & individual $\mathrm{km}^{-2}$ \\
\hline $\mathrm{RH}$ & Relative humidity (\%) & - \\
\hline $\mathrm{RH}_{\text {low }}$ & Lower relative humidity threshold $(\%)$ & - \\
\hline $\mathrm{RH}_{\mathrm{up}}$ & Upper relative humidity threshold (\%) & - \\
\hline$u_{\mathrm{b}}$ & Fire spread rate in the upwind direction & $\mathrm{m} \mathrm{s}^{-1}$ \\
\hline$u_{\max }$ & Average maximum fire spread rate & $\mathrm{m} \mathrm{s}^{-1}$ \\
\hline$u_{\mathrm{p}}$ & Fire spread rate in the downwind direction & $\mathrm{m} \mathrm{s}^{-1}$ \\
\hline$v$ & Fire spread rate perpendicular to the wind direction & $\mathrm{m} \mathrm{s}^{-1}$ \\
\hline$w$ & Length of minor axis of elliptical post-fire region & $\mathrm{m}$ \\
\hline$W$ & Wind speed & $\mathrm{m} \mathrm{s}^{-1}$ \\
\hline$\alpha$ & Monthly potential ignition counts per person & count person ${ }^{-1}$ mon $^{-1}$ \\
\hline$\beta$ & Root zone soil wetness & - \\
\hline$\phi_{j}$ & Fire carbon emissions of the $j$-th PFT & $\mathrm{g} \mathrm{C}(\text { time step })^{-1}$ \\
\hline$\lambda$ & Latitude & $\circ$ \\
\hline$\theta$ & Surface soil wetness & - \\
\hline$\theta_{\mathrm{e}}$ & Extinction soil wetness & - \\
\hline$\xi_{j}$ & Whole-plant mortality factor of the $j$-th PFT & - \\
\hline$\tau$ & Average fire duration & $\mathrm{s}$ \\
\hline$\Psi$ & Cloud-to-ground lightning fraction & - \\
\hline$\Psi_{j}$ & Tissue mortality & $\mathrm{g} \mathrm{C} \mathrm{km}^{-2}{\text { (time step })^{-1}}^{-1}$ \\
\hline
\end{tabular}


Acknowledgements. This study is co-supported by the State Key Project for Basic Research Program of China (973) under Grant No. 2010CB951801, the State High-Tech Development Plan of China (863) under Grant No. 2009AA122105, and the Key Program of National Natural Science Foundation under Grant No. 40830103. We are grateful to X. Yue from Harvard University, G. R. van der Werf from VU University in Netherlands, and L. Giglio from NASA Goddard Space Flight Center for helpful discussions, and M. O. Andreae from Max Planck Institute for Chemistry in Germany for the latest emission factors of trace gases and aerosols due to biomass burning. We also thank K. Thonicke, V. K. Arora, and two anonymous reviewers for valuable comments and suggestions.

Edited by: K. Thonicke

\section{References}

Albini, F. A. and Stocks, B. J.: Predicted and observed rates of spread of crown fires in immature jack pine, Combust. Sci. Technol., 48, 65-76, 1986.

Andreae, M. O. and Merlet, P.: Emission of trace gases and aerosols from biomass burning, Global Biogeochem. Cy., 15, 955-966, 2001.

Andreae, M. O., Rosenfeld, D., Artaxo, P., Costa, A. A., Frank, G. P., Longo, K. M., and Silva-Dias, M. A. F.: Smoking rain clouds over the Amazon, Science, 303, 1337-1342, 2004.

Archibald, S., Roy, D. P., van Wilgen, B. W., and Scholes, R. J.: What limits fire? An examination of drivers of burnt area in Southern Africa, Glob. Change Biol., 15, 613-630, doi:10.1111/j.1365-2486.2008.01754.x, 2009.

Arora, V. K.: Simulating energy and carbon fluxes over winter wheat using coupled land surface and terrestrial ecosystem models, Agr. Forest. Meteorol., 118, 21-47, 2003.

Arora, V. K. and Boer, G. J.: Fire as an interactive component of dynamic vegetation models, J. Geophys. Res., 110, G02008, doi:10.1029/2005JG000042, 2005.

Bachelet, D., Neilson, R. P., Hickler, T., Drapek, R. J., Lenihan, J. M., Sykes, M. T., Smith, B., Sitch, S., and Thonicke, K.: Simulating past and future dynamics of natural ecosystems in the United States, Global Biogeochem. Cy., 17, 1045, doi:10.1029/2001GB001508, 2003.

Bonan, G. B., Levis, S., Kergoat, L., and Oleson, K. W.: Landscapes as patches of plant functional types: An integrating concept for climate and ecosystem models, Global Biogeochem. Cy., 16, 1021, doi:10.1029/2000GB001360, 2002.

Bond, W. J., Woodward, F., and Midgley, G. F.: The global distribution of ecosystems in a world without fire, New Phytol., 165, 525-538, doi:10.1111/j.1469-8137.2004.01252.x, 2004.

Bond-Lamberty, B., Peckham, S. D., Gower, S. T., and Ewers, B. E.: Effects of fire on regional evapotranspiration in the central Canadian boreal forest, Glob. Change Biol., 15, 1242-1254, doi:10.1111/j.1365-2486.2008.01776.x, 2009.

Brovkin, V., Claussen, M., Driesschaert, E., Fichefet, T., Kicklighter, D., Loutre, M. F., Matthews, H. D., Ramankutty, N., Schaeffer, M., and Sokolov, A.: Biogeophysical effects of historical land cover changes simulated by six Earth System Models of intermediate complexity, Clim. Dynam., 26, 587-600, doi:10.1007/s00382-005-0092-6, 2006.
Bowman, D. M. J. S., Balch, J. K., Artaxo, P., Bond, W. J., Carlson, J. M., Cochrane, M. A., D’Antonio, C. M., DeFries, R. S., Doyle, J. C., Harrison, S. P., Johnston, F. H., Keeley, J. E., Krawchuk, M. A., Kull, C. A., Marston, J. B., Mortiz, M. A., Prentice, I. C., Roos, C. I., Scott, A. C., Swetnam, T. W., van der Werf, G. R., and Pyne, S. J.: Fire in the Earth System, Science, 324, 480-484, doi:10.1126/science.1163886, 2009.

Castillo, C. K. G., Levis, S., and Thornton, P. E.: Evaluation of the New CNDV Option of the Community Land Model: Effects of Dynamic Vegetation and Interactive Nitrogen on CLM4 Means and Variability, J. Climate, 25, 3702-3714, doi:10.1175/JCLI-D11-00372.1, 2012.

Chambers, S. D. and Chapin III, F. S.: Fire effects on surfaceatmosphere energy exchange in Alaskan black spruce ecosystems: Implications for feedbacks to regional climate, J. Geophys. Res., 108, 8145, doi:10.1029/2001JD000530, 2002.

Chen, M: Couple the Common Land Model with the dynamic global vegetation model, M. S. thesis, Institute of Atmospheric physics, Chinese Academy of Sciences, Beijing, China, 2008.

Chuvieco, E., Giglio, L., and Justice, C.: Global characterization of fire activity: Toward defining fire regimes from Earth observation data, Glob. Change Biol., 14, 1488-1502, doi:10.1111/j.13652486.2008.01585.x, 2008.

CIESIN: Gridded population of the world version 3(GPWv3): Population density grids, Technical report, Socioeconomic Data and Applications Center (SEDAC), Columbia University, Palisades, New York, USA, 2005.

Cochrane, M. A. and Ryan, K. C.: Fire and fire ecology: Concepts and principles, in: Tropical Fire Ecology: Climate Change, Land Use and Ecosystem Dynamics, M. A. Cochrane, SpringerPRAXIS, Heidelberg, Germany and Chichester, UK, 25-62, 2009.

Cox, P. M.: Description of the TRIFFID dynamic global vegetation model, Tech. Note 24, Hadley Cent., Bracknell, UK, 16 pp., 2001.

Czimczik, C. I., Preston, C. M., Schmidt, M. W. I., and Schulze, E. D.: How surface fire in Siberian Scots pine forests affects soil organic carbon in the forest floor: Stocks, molecular structure, and conversion to black carbon (charcoal), Global Biogeochem. Cy., 17, 1020, doi:10.1029/2002GB001956, 2003.

Dai, Y., Zeng, X. B., Dickenson, R. E., Baker, I., Bonan, G. B., Bosilovich, M. G., Denning, A. S., Dirmeyer, P.A., and Houser, P. R.: The Common Land Model, B. Am. Meteorol. Soc., 84, 1013-1023, doi:10.1175/BAMS-84-8-1013, 2003.

Day, C.: Smoke from burning vegetation changes the coverage and behavior of clouds, Phys. Today, 57, 24-26, 2004.

Delire, C., de Noblet-Ducoudré, N., Sima, A., and Gouirand, I.: Vegetation dynamics enhancing long-term climate variability confirmed by two models, J. Climate, 24, 2238-2257, doi:10.1175/2010JCLI3664.1, 2011.

Fan, Y. and van den Dool, H.: Climate Prediction Center global monthly soil moisture data set at $0.5^{\circ}$ resolution for 1948 to present, J. Geophys. Res., 109, D10102, doi:10.1029/2003JD004345, 2004.

Foley, J. A., Prentice, I. C., Ramankutty, N., Levis, S., Pollard, D., Sitch, S., and Haxeltine, A.: An integrated biosphere model of land surface processes, terrestrial carbon balance, and vegetation dynamics, Global Biogeochem. Cy., 10, 603-628, doi:10.1029/96GB02692, 1996. 
Fosberg, M. A., Cramer, W., Brovkin, V., Fleming, R., Gardner, R., Gill, A.M., Goldammer, J. G., Keane, R., Koehler, P., Lenihan, J., Neilson, R., Sitch, S., Thonicke, K., Venevski, S., Weber, M. G., and Wittenberg, U.: Strategy for a fire module in dynamic global vegetation models, Int. J. Wildland Fire, 9, 79-84, 1999.

Giglio, L., Csiszar, I., and Justice, C. O.: Global distribution and seasonality of active fires as observed with the Terra and Aqua Moderate Resolution Imaging Spectroradiometer (MODIS) sensors, J. Geophys. Res., 111, G02016, doi:10.1029/2005JG000142, 2006.

Giglio, L., Randerson, J. T., van der Werf, G. R., Kasibhatla, P. S., Collatz, G. J., Morton, D. C., and DeFries, R. S.: Assessing variability and long-term trends in burned area by merging multiple satellite fire products, Biogeosciences, 7, 1171-1186, doi:10.5194/bg-7-1171-2010, 2010.

Hoffmann, W. A., Orthen, B., and do Nascimento, P. K. V.: Comparative fire ecology of tropical savanna and forest trees, Funct. Ecol., 17, 720-726, 2003.

IPCC: Climate Change 2007: The Physical Science Basis, Contribution of Working Group I to the Fourth Assessment Report of the Intergovernmental Panel on Climate Change, edited by: Solomon, S., Qin, D., Manning, M., Chen, Z., Marquis, M., Averyt, K. B., Tignor, M., and Miller, H. L., Cambridge University Press, Cambridge, UK and New York, NY, USA, 2007.

Klein Goldewijk, K., Beusen, A., and Janssen, P.: Long term dynamic modeling of global population and built-up area in a spatially explicit way, HYDE 3.1, The Holocene, 20, 565-573, 2010.

Kloster, S., Mahowald, N. M., Randerson, J. T., Thornton, P. E., Hoffman, F. M., Levis, S., Lawrence, P. J., Feddema, J. J., Oleson, K. W., and Lawrence, D. M.: Fire dynamics during the 20th century simulated by the Community Land Model, Biogeosciences, 7, 1877-1902, doi:10.5194/bg-7-1877-2010, 2010.

Korontzi, S., McCarty, J., Loboda, T., Kumar, S., and Justice, C.: Global distribution of agricultural fires in croplands from 3 years of Moderate Resolution Imaging Spectroradiometer (MODIS) data, Global Biogeochem. Cy., 20, GB2021, doi:10.1029/2005GB002529, 2006.

Krinner, G., Viovy, N., de Noblet-Ducoudré, N., Ogee, J., Polcher, J., Friedlingstein, P., Ciais, P., Sitch, S., and Prentice, I. C.: A dynamic global vegetation model for studies of the coupled atmosphere-biosphere system, Global Biogeochem. Cy., 19, GB1015, doi:10.1029/2003GB002199, 2005.

Kucharik, C. J., Foley, J. A., Delire, C., Fisher, V. A., Coe, M. T., Lenters, J. D., Young-Molling, C., and Ramankutty, N.: Testing the performance of a dynamic global ecosystem model: Water balance, carbon balance, and vegetation structure, Global Biogeochem. Cy., 14, 795-825, 2000.

Lawrence, P. J. and Chase, T. N: Representing a new MODIS consistent land surface in the Community Land Model (CLM 3.0), J. Geophys. Res., 112, G01023, doi:10.1029/2006JG000168, 2007.

Lawrence, P. J. and Chase, T. N.: Investigating the climate impacts of global land cover change in the community climate system model, Int. J. Climatol., 30, 2066-2087, 2010.

Lawrence, D., Oleson, K. W., Flanner, M. G., Thorton, P. E., Swenson, S. C., Lawrence, P. J., Zeng, X., Yang, Z. L., Levis, S., Skaguchi, K., Bonan, G. B., and Slater, A. G.: Parameterization Improvements and Functional and Structural Advances in Version 4 of the Community Land Model, J. Adv. Model. Earth Syst., 3, 27 pp., 2011.
Lenihan, J. M. and Neilson, R. P.: Simulating broad-scale fire severity in a dynamic global vegetation model, Northwest Sci., 72, 91-103, 1998.

Levis, S., Foley, J. A., Brovkin, V., and Pollard, D.: On the stability of the high-latitude climate-vegetation system in a coupled atmosphere-biosphere model, Glob. Ecol. Biogeogr., 8, 489-500, 1999.

Levis, S., Bonan, G. B., Vertenstein, M., and Oleson, K. W.: The Community Land Model's Dynamic Global Vegetation Model (CLM-DGVM): Technical description and user's guide, NCAR Tech. Note TN-459_IA, Terrestrial Sciences Section, Boulder, Colorado, 2004.

Lindsey, D. T. and Fromm, M.: Evidence of the cloud lifetime effect from wildfire-induced thunderstorms, Geophys. Res. Lett., 35, L22809, doi:10.1029/2008GL035680, 2008.

McKenzie D., Raymond, C. L., Kellogg, L. K. B., Norheim, R. A., Andreu, A. G., Bayard, A. C., Kopper, K. E., and Elman, E.: Mapping fuels at multiple scales: landscape application of the Fuel Characteristic Classification System, Can. J. Forest Res., 37, 2421-2437, 2007.

Moorcroft, P. R., Hurtt, G. C., and Pacala, S. W.: A method for scaling vegetation dynamics: The ecosystem demography model (ED), Ecol. Monogr., 71, 557-586, 2001.

Oleson, K. W., Lawrence, D. M., Bonan, G. B., Flanner, M. G., Kluzek, E., Lawrence, P. J., Levis, S., Swenson, S. C., Thornton, P. E., Dai, A., Decker, M., Dickinson, R., Feddema, J., Heald, C. L., Hoffman, F., Lamarque, J. F., Mahowald, N., Niu, G. Y., Qian, T., Randerson, J., Running, S., Sakaguchi, K., Slater, A., Stockli, R., Wang, A., Yang, Z. L., Zeng, X. D., and Zeng, X.: Technical description of version 4.0 of the Community Land Model, NCAR Tech. Note NCAR/TN-478+STR, Terrestrial Sciences Section, Boulder, Colorado, 2010.

Ottmar R. D., Sandberg, D. V., Riccardi, C. L., and Prichard, S. J.: An overview of the Fuel Characteristic Classification System Quantifying, classifying, and creating fuelbeds for resource planning, Can. J. Forest Res., 37, 2383-2393, 2007.

Pechony, O. and Shindell, D. T.: Fire parameterization on a global scale, J. Geophys. Res., 114, D16115, doi:10.1029/2009JD011927, 2009.

Prentice, S. A. and Mackerras, D.: The ratio of cloud to cloudground lightning flashes in thunderstorms, J. Appl. Meteorol., 16, 545-550, 1977.

Prentice, I. C., Kelley, D. I., Foster, P. N., Friedlingstein, P., Harrison, S. P., and Bartlein, P. J.: Modeling fire and the terrestrial carbon balance, Global Biogeochem. Cy., 25, GB3005, doi:10.1029/2010GB003906, 2011.

Price, C. and Rind, D.: Modeling global lightning distributions in a general circulation model, Mon. Weather Rev., 122, 1930-1939, 1994.

Qian, T., Dai, A., Trenberth, K. E., and Oleson, K. W.: Simulation of global land surface conditions from 1948 to 2004, Part I: Forcing data and evaluations, J. Hydrometeorol., 7, 953-975, 2006.

Quillet, A., Peng C. H., and Garneau, M.: Toward dynamic global vegetation models for simulating vegetation-climate interactions and feedbacks: recent developments, limitations, and future challenges, Environ. Rev., 18, 333-353, 2010.

Riggan, P. J., Tissell, R. G., Lockwood, R. N., Brass, J. A., Pereira, J. A. R., Miranda, H. S., Miranda, A. C., Campos, T., and Higgins, R.: Remote measurement of energy and carbon flux from 
wildfires in Brazil, Ecol. Appl., 14, 855-872, 2004.

Rosa, I. M. D., Pereira, J. M. C., and Tarantola, S.: Atmospheric emissions from vegetation fires in Portugal (1990-2008): estimates, uncertainty analysis, and sensitivity analysis, Atmos. Chem. Phys., 11, 2625-2640, doi:10.5194/acp-11-2625-2011, 2011.

Sato, H., Itoh A., and Kohyama T.: SEIB-DGVM: a new dynamic global vegetation model using a spatially explicit individualbased approach, Ecol. Model., 200, 279-307, 2007.

Schoennagel, T., Veblen, T., and Romme, W.: Interaction of fire, fuels, and climate across Rocky Mountain forests, Bioscience, 54, 661-676, 2004.

Schultz, M. G., Heil, A., Hoelzemann, J. J., Spessa, A., Thonicke, K., Goldammer, J. G., Held, A. C., Pereira, J. M. C., and van het Bolscher, M.: Global wildland fire emissions from 1960 to 2000, Global Biogeochem. Cy., 22, GB2002, doi:10.1029/2007GB003031, 2008.

Shinoda, M. and Yamaguchi, Y.: Influence of soil moisture anomaly on temperature in the Sahel: A comparison between wet and dry decades, J. Hydrometeorol., 4, 437-447, 2003.

Sitch, S., Smith, B., Prentice, I. C., Arneth, A., Bondeau, A., Cramer, W., Kaplan, J. O., Levis, S., Lucht, W., Sykes, M. T., Thonicke, K., Venevsky, S.: Evaluation of ecosystem dynamics, plant geography and terrestrial carbon cycling in the LPJ dynamic global vegetation model, Glob. Change Biol., 9, 161-185, doi:10.1046/j.1365-2486.2003.00569.x, 2003.

Sousa, W. P.: The role of disturbance in natural communities, Annu. Rev. Ecol. Syst., 15, 353-391, 1984.

Spracklen, D. V., Mickley, L. J., Logan, J. A., Hudman, R. C., Yevich, R., Flannigan, M. D., and Westerling, A. L.: Impacts of climate change from 2000 to 2050 on wildfire activity and carbonaceous aerosol concentrations in the western United States, J. Geophys. Res., 114, D20301, doi:10.1029/2008JD010966, 2009.

Thonicke, K., Venevsky, S., Sitch, S., and Cramer, W.: The role of fire disturbance for global vegetation dynamics: Coupling fire into a dynamic global vegetation model, Global Ecol. Biogeogr., 10, 661-677, 2001.

Thonicke, K., Prentice, I. C., and Hewitt, C.: Modeling glacial-interglacial changes in global fire regimes and trace gas emissions, Global Biogeochem. Cy., 19, GB3008, doi:10.1029/2004GB002278, 2005.

Thonicke, K., Spessa, A., Prentice, I. C., Harrison, S. P., Dong, L., and Carmona-Moreno, C.: The influence of vegetation, fire spread and fire behaviour on biomass burning and trace gas emissions: results from a process-based model, Biogeosciences, 7, 1991-2011, doi:10.5194/bg-7-1991-2010, 2010.

Thornton, P. E., Lamarque, J., Rosenbloom, N., and Mahowald, N.: Influence of carbon-nitrogen cycle coupling on land model response to $\mathrm{CO}_{2}$ fertilization and climate variability, Global Biogeochem. Cy., 21, GB4018, doi:10.1029/2006GB002868, 2007.
Thornton, P. E., Levis, S., and C-LAMP team: CLM-CN update: progress toward CLM4.0, in the 13th Annual CCSM Workshop, National Science Foundation and the US Department of Energy, Breckenridge, Colorado, 2008.

van der Werf, G. R., Randerson, J. T., Giglio, L., Collatz, G. J., Kasibhatla, P. S., and Arellano Jr., A. F.: Interannual variability in global biomass burning emissions from 1997 to 2004, Atmos. Chem. Phys., 6, 3423-3441, doi:10.5194/acp-6-3423-2006, 2006.

van der Werf, G. R., Randerson, J. T., Giglio, L., Gobron, N., and Dolman, A. J.: Climate controls on the variability of fires in the tropics and subtropics, Global Biogeochem. Cy., 22, GB3028, doi:10.1029/2007GB003122, 2008.

van der Werf, G. R., Randerson, J. T., Giglio, L., Collatz, G. J., Mu, M., Kasibhatla, P. S., Morton, D. C., DeFries, R. S., Jin, Y., and van Leeuwen, T. T.: Global fire emissions and the contribution of deforestation, savanna, forest, agricultural, and peat fires (19972009), Atmos. Chem. Phys., 10, 11707-11735, doi:10.5194/acp10-11707-2010, 2010.

Vega, J. A., Fernandes, P., Cuiñas, P., Fontúrbel, T., Pérez, J. R., P., and Loureiro, C.: Fire spread analysis of early summer field experiments in shrubland fuel types of northwestern Iberia, Forest Ecol. Manag., 234S, S102 pp., doi:10.1016/j.foreco.2006.08.138, 2006.

Venevsky, S., Thonicke, K., Sitch, S., and Cramer, W.: Simulating fire regimes in human-dominated ecosystems: Iberian Peninsula case study, Glob. Change Biol., 8, 984-998, 2002.

Vigilante, T., Bowman, D. M. J. S., Fisher, R., Russell-Smith, J., and Yates, C.: Contemporary landscape burning patterns in the far North Kimberley region of north-west Australia: Human influences and environmental determinants, J. Biogeogr., 31, 13171333, 2004.

Wang, X. X., Liu, Z. Z., Wu, S. Y., Chen, Z. Z., Liu, X. Z., Shi, S. C., Wang, A. M., Song, Q. F., and Liu, Y.: China Forest FireDanger Weather Grading Criteria, Rep. LY/T 1172-1995, State Forestry Administration, P. R. China, Beijing, China, 1995.

Woodward, F. I. and Lomas M. R.: Vegetation dynamics-simulation responses to climatic change, Biol. Rev., 79, 643-670, 2004.

Zeng, N., Mariotti, A., and Wetzel, P.: Terrestrial mechanisms of interannual CO2 variability, Global Biogeochem. Cy., 19, GB1016, doi:10.1029/2004GB002273, 2005.

Zeng, X. D.: Evaluating the dependence of vegetation on climate in an improved dynamic global vegetation model, Adv. Atmos. Sci., 27, 977-991, doi:10.1007/s00376-009-9186-0, 2010.

Zeng, X. D., Zeng, X., and Barlage, M.: Growing temperate shrubs over arid and semiarid regions in the NCAR dynamic global vegetation model (CLM-DGVM), Global Biogeochem. Cy., 22, GB3003, doi:10.1029/2007GB003014, 2008.

Zhou, G. S. and Lu, Q.: Meteorology and Fires in Forests and Grassland, China Meteorological Press, Beijing, 2009. 